OPEN ACCESS

Edited by:

Mark Meekan,

Australian Institute of Marine Science

(AIMS), Australia

Reviewed by:

Johanna Zimmerhackel,

University of Western Australia,

Australia

Charlie Huveneers,

Flinders University, Australia

*Correspondence:

Enrique Sanjurjo-Rivera

sanjurjo73@hotmail.com

Specialty section: This article was submitted to

Marine Megafauna,

a section of the journal

Frontiers in Marine Science

Received: 19 December 2020

Accepted: 04 May 2021

Published: 27 August 2021

Citation:

Sanjurjo-Rivera E, Mesnick SL,

Ávila-Forcada S, Poindexter O,

Lent R, Felbab-Brown V,

Cisneros-Montemayor AM, Squires $D$

Sumaila UR, Munro G,

Ortiz-Rodriguez $R$, Rodriguez $R$ and

Sainz JF (2021) An Economic

Perspective on Policies to Save the Vaquita: Conservation Actions, Wildlife Trafficking, and the Structure

of Incentives.

Front. Mar. Sci. 8:644022.

doi: 10.3389/fmars.2021.644022

\section{An Economic Perspective on Policies to Save the Vaquita: Conservation Actions, Wildlife Trafficking, and the Structure of Incentives}

\author{
Enrique Sanjurjo-Rivera ${ }^{*}$, Sarah L. Mesnick², Sara Ávila-Forcada ${ }^{3}$, Oriana Poindexter ${ }^{4}$, \\ Rebecca Lent ${ }^{5}$, Vanda Felbab-Brown ${ }^{6}$, Andrés M. Cisneros-Montemayor ${ }^{7}$, \\ Dale Squires ${ }^{2}$, U. Rashid Sumaila ${ }^{8}$, Gordon Munro ${ }^{9}$, Rafael Ortiz-Rodriguez ${ }^{10}$, \\ Ramses Rodriguez ${ }^{11}$ and Jade F. Sainz ${ }^{12}$
}

\begin{abstract}
' Fisheries Economics Consultant, La Paz, Mexico, ${ }^{2}$ Southwest Fisheries Science Center, National Marine Fisheries Service, National Oceanic and Atmospheric Administration, La Jolla, CA, United States, ${ }^{3}$ Department of Economics and Continuing Education, University of Colorado, Boulder, CO, United States, ${ }^{4}$ Ocean Associates, Inc., under contract to Southwest Fisheries Science Center, National Marine Fisheries Service, National Oceanic and Atmospheric Administration, La Jolla, CA, United States, ${ }^{5}$ International Whaling Commission, Cambridge, United Kingdom, ${ }^{6}$ The Brookings Institution, Washington, DC, United States, ${ }^{7}$ Nippon Foundation Ocean Nexus, Institute for the Oceans and Fisheries, University of British Columbia, Vancouver, BC, Canada, ${ }^{8}$ Fisheries Economics Research Unit, Institute for the Oceans and Fisheries and the School of Public Policy and Global Affairs, University of British Columbia, Vancouver, BC, Canada, ${ }^{9}$ Vancouver School of Economics, Institute for the Oceans and Fisheries, University of British Columbia, Vancouver, BC, Canada, ${ }^{10}$ Environmental Defense Fund de México A.C., La Paz, Mexico, ${ }^{11}$ Fundación Verde Ser Natura, Hermosillo, Mexico, ${ }^{12}$ Bren School of Environmental Science and Management, University of California, Santa Barbara, Santa Barbara, CA, United States
\end{abstract}

The Upper Gulf of California is a diverse and highly productive ecosystem supporting some of the most important fisheries in Mexico, yet a history of weak fisheries management and illegal fishing threaten the area's biodiversity and undermine human well-being in the communities along its shores. The vaquita (Phocoena sinus) is endemic to these waters and is on the brink of extinction due to incidental entanglement in gillnets used by small-scale fishers. The resurgence of an illegal gillnet fishery for totoaba (Totoaba macdonaldi), whose swim bladders are highly prized in Hong Kong and continental China, has accelerated the steep decline of the vaquita population. Vaquita is one of a growing number of cases linking illegal wildlife trade, organized crime, and biodiversity decline. This paper provides a summary of key reflections of a panel of fisheries economists gathered at the ninth forum of the North American Association of Fisheries Economists (NAAFE) to evaluate the policies implemented in the Upper Gulf through an economic lens and updated to reflect more recent developments. The panel recognized that poor fisheries management, lack of effective enforcement, distant demand for an illegal product, corruption, and few viable economic alternatives confound efforts to address vaquita bycatch. The complexity of these problems requires a holistic, multidisciplinary approach, combining topdown, direct regulation and bottom-up, participatory and incentive-based instruments. 
Addressing chronic deficiencies in enforcement, particularly in the very small area where the remaining vaquitas are found, is crucial to prevent imminent extinction. Equally crucial are sustained actions to support legal fishers able to make a good living - with a direct stake in healthy marine ecosystems - as key components of policies to address bycatch and reduce wildlife trafficking. The situation in the Upper Gulf of California is dire, yet similar threats to other marine mammals and wildlife trafficked species may benefit from the experience of the vaquita.

Keywords: vaquita, totoaba, bycatch, ilegal wildlife trafficking, incentive-based management, conservation

\section{INTRODUCTION}

Mexico's endemic porpoise, the vaquita (Phocoena sinus), is the world's most critically endangered marine mammal (International Union for the Conservation of Nature [IUCN], 2020b). It is endemic to the upper Gulf of California (UGC) where unsustainable bycatch in small-scale gillnet fisheries has long been recognized as the only factor driving the species toward extinction (Norris and Prescott, 1961; Brownell, 1988; RojasBracho and Taylor, 1999; D'Agrosa et al., 2000; Rojas-Bracho et al., 2006). Since the early 2010s, the resurgence of illegal fishing for totoaba (Totoaba macdonaldi), driven by the black market for totoaba swim bladders in Hong Kong and continental China, has caused vaquita numbers to plummet at nearly $50 \%$ per year (Jaramillo-Legorreta et al., 2019). In summer 2018, the population estimate indicated fewer than 19 individuals remain (Jaramillo-Legorreta et al., 2019). The last best estimate from the area where vaquitas were most recently detected acoustically estimated 10 individuals, including 3 calves, and all appeared in good health (Rojas-Bracho et al., 2020). Ensuring protection of these surviving vaquitas from gillnets could still save the species (Morin et al., 2020; Rojas-Bracho et al., 2020; International Whaling Commission [IWC], 2021).

A number of governmental policies and programs have been enacted in the UGC to protect vaquita from gillnets (see reviews in Rojas-Bracho et al., 2006; Bobadilla et al., 2011; Rojas-Bracho and Reeves, 2013; Cisneros-Montemayor and Vincent, 2016). Despite these efforts, the region continues to experience widespread illegal fishing with gillnets, loss of income and markets for legal fishers, and the continued decline of the vaquita population (Comité Internacional para la Recuperación de la Vaquita [CIRVA], 2019; United Nations Educational, Scientific and Cultural Organization [UNESCO], 2019; International Union for the Conservation of Nature [IUCN], 2020b; International Whaling Commission [IWC], 2021). Illegal and unsustainable fishing threatens the region's rich biodiversity and undermines the economic and human potential of the communities. Formal and informal institutions ${ }^{1}$ are challenged to protect the region's natural resources due to the increasing presence of organized crime and a history of tolerated corruption and non-compliance with regulations (C4ADS, 2017;

\footnotetext{
${ }^{1}$ Understanding institutions as the "rules of the game," both the formal legal rules and the informal social norms that govern individual behavior and structure social interactions (North, 1990).
}

Crosta et al., 2018; Environmental Investigation Agency [EIA], 2019; Aceves-Bueno et al., 2020; Felbab-Brown, 2020).

This article contends that resolving protected species bycatch in small scale fisheries requires addressing underlying issues of fisheries management and governance and, equally crucially, in finding viable alternative methods of fishing and economic activities for local communities. In the case of vaquita, the need for a multifaceted approach has been championed by the international vaquita recovery team since its inception (Comité Internacional para la Recuperación de la Vaquita [CIRVA], 1997, 2014, 2019), recommended by international organizations (United Nations Educational, Scientific and Cultural Organization [UNESCO], 2018; International Whaling Commission [IWC], 2019; International Union for the Conservation of Nature [IUCN], 2020b), scientists (Rojas-Bracho et al., 2006; Bobadilla et al., 2011; Rojas-Bracho and Reeves, 2013; Aburto-Oropeza et al., 2016; Cisneros-Montemayor and Vincent, 2016; Aceves-Bueno et al., 2020), and recognized in the policies of the Government of Mexico. However, enacted policies failed to fully embrace the long-term investment necessary for successful community engagement and economic development that can generate buy-in and improve compliance by providing lasting benefits. These well-intentioned programs also failed to consider the consequences of conservation policy on local communities. The problems in the UGC were exacerbated well beyond the ability of traditional fisheries management to provide solutions due to corruption and the related illegal and lucrative alternative, the black market for totoaba swim bladders.

A panel convened at the ninth forum of the North American Association of Fisheries Economists reviewed conservation actions that had been implemented to protect vaquita and support local communities. This paper provides a brief history of the government policies applied in the region, followed by a review of socio-economic instruments and impacts, both intended and unintended. Key points and recommendations from the panel are summarized and updated to reflect policies enacted through early 2021. The focus is on the interplay between top-down, direct regulation and bottom-up, incentive-based ${ }^{2}$ approaches (Squires et al., 2021), the external pressures from

\footnotetext{
2 "Incentive-based" instruments refer to all kinds of instruments that could change human behavior without having to command the change in behavior via a direct regulation. Such kinds of instruments could include: property-based instruments (fishing quotas, territorial use rights for fisheries); economic instruments (taxing the conduct or activity that the regulator wants to decrease); market instruments (cap and trade policies); or correcting information asymmetries, among others.
} 
the totoaba black market, and how these factors altered the structure of incentives that drive decisions about fishing in the region. While the situation for vaquita is dire, similar threats to other marine mammals (Brownell et al., 2019) and other trafficked wildlife species (Felbab-Brown, 2017) may benefit from the experience of the UGC.

\section{BACKGROUND}

\section{Small-Scale Gillnet Fisheries in the Upper Gulf of California}

The UGC is a highly productive marine ecosystem supporting some of the most profitable and seasonally diverse smallscale fishery resources in Mexico (Erisman et al., 2015; Brusca et al., 2017). Gillnets have been used in the UGC since the 1930s, initially for sharks and totoaba, and then adapted for other species over the ensuing decades. With mesh sizes ranging from about 7 to $30 \mathrm{~cm}$ depending on target species, the nets are easy to deploy and costeffective to use given the strong tidal currents in the area. Currently, gillnets are used to harvest several high value species: blue shrimp (Litopenaeus stylirostris) and brown shrimp (Farfantepenaeus californianus) from September to March; Gulf corvina (Cynoscion othonopterus) in March and April; and sharks, rays, and several kinds of finfish, such as bigeye croaker (Micropogonias megalops) and Spanish mackerel (Scomberomorus concolor) from February to June (CudneyBueno and Turk-Boyer, 1998; Erisman et al., 2015). These fisheries are major contributors of income, employment, and food security in the coastal communities and also provide a strong sense of cultural identity and social relevance (Lluch-Cota et al., 2007).

The most recent assessment of small-scale fisheries in the region (Pérez-Valencia et al., 2015; Appendix 1) indicated that there were 1,688 fishing licenses for 876 registered pangas. Pangas are fiberglass, outboard-powered boats 6 to 8 meters long, each operating with two or three local crew members (Cudney-Bueno and Turk-Boyer, 1998). Given the multiple target species, most fishers need two or more licenses to fish throughout the year, the average being 1.92 licenses per panga. Appendix 1 shows the distribution of licenses and pangas among the three main fishing towns in the UGC in 2015, the most recent year for which reliable data were available ${ }^{3}$. The level of fishing effort in 2015 reflects the impacts of policies analyzed in this paper.

The local economies of San Felipe in Baja California (population in $2018 \sim 19,000$ ) and El Golfo de Santa Clara in Sonora (population in $2010 \sim 4,000$ ) are largely dependent

\footnotetext{
${ }^{3}$ Fisheries authorities never completed the census of fishers in the UGC. However, given the UGC is a designated natural protected area, all economic activities (including fisheries) are required to present an Environmental Impact Assessment (EIA). Fishers without an EIA authorization would not be able to obtain the permits issued by the port authorities to go fishing; this makes the list of vessels and fishers included at the EIA the most reliable data on the real fishing effort in the region. In 2015, an expansion of the Vaquita Refuge as a No Take Zone, was a de facto fishing ban. Since then, fishers have not presented an EIA, making the information from 2015 the most reliable data for the fishing effort in the region.
}

on fisheries that overlap with vaquita habitat (Cudney-Bueno and Turk-Boyer, 1998; Erisman et al., 2015). The Cucapá, an Indigenous community of the Colorado River Delta, and smallscale fishers from Puerto Peñasco in Sonora (population in $2020 \sim 62,000$ ), fish in the UGC but primarily outside of vaquita habitat.

A broad range of problems threaten the long-term sustainability of the region's fisheries resources and biodiversity, including the population trends for vaquita and totoaba (Rojas-Bracho and Reeves, 2013; Cisneros-Montemayor and Vincent, 2016; Cisneros-Mata, 2020). The complex socioecological context, and a host of underlying institutional deficiencies at multiple levels, hinder efforts to implement more sustainable practices. These include a lack of inter-agency coordination, conflict among stakeholders and between fisheries and conservation policies, limited institutional capacity, lack of enforcement and compliance, corruption, and weak fisheries management that has resulted in open-access, overcapitalized fisheries with high levels of IUU (illegal, underreported unregulated) fishing (Lluch-Cota et al., 2007; Cisneros-Mata, 2010; Bobadilla et al., 2011; Erisman et al., 2011; CisnerosMontemayor et al., 2013; C4ADS, 2017; Pasini et al., 2017; Crosta et al., 2018; Mangin et al., 2018; International Union for the Conservation of Nature [IUCN], 2020a,b; Cisneros-Mata, 2020; Felbab-Brown, 2020).

Before the re-emergence of the illegal totoaba fishery, gillnet fisheries for blue shrimp were the most profitable. Most of the product was exported to the U.S. market where the high quality, large size class UGC shrimp commands high prices (Ardjosoediro and Bourns, 2009; Mesnick et al., 2019). From 2001 to 2011, 53 and $58 \%$ of gross revenues from fishing in El Golfo de Santa Clara and San Felipe, respectively, were from blue shrimp (Erisman et al., 2015). Net annual profit per panga for shrimp has been estimated at 2,200 USD in El Golfo de Santa Clara and 2,700 USD in San Felipe (Barlow et al., 2010). Total ex-vessel gross revenues from all target species for both communities are estimated at less than 20M USD (Barlow et al., 2010; Erisman et al., 2015). Net earnings, however, vary widely among permit owners depending on the number of boats and permits they hold. While these are admittedly imprecise estimates of income, they nevertheless provide a general indication of the net income from fishing and therefore, provide a useful basis for considering the attraction of other economic activities.

\section{Totoaba Poaching and the Black Market for Totoaba Swim Bladders}

Totoaba - a large (up to $2 \mathrm{~m}$ and over $100 \mathrm{~kg}$ ) long-lived sciaenid that congregates in large schools to spawn in the shallow waters of the UGC - has driven the development and fate of the communities of the UGC for nearly a century. The high value of totoaba brought early prospectors to the UGC in the 1920s as they responded to demand for the fish's swim bladder. The swim bladders were initially consumed by the region's Chinese immigrants and then later exported to China and the Chinese communities of California for a highly valued soup, while the meat was most often left on the beach (Chute, 
1928, 1930; Flanagan and Hendrickson, 1976; Cisneros-Mata et al., 1995). The history of totoaba in the UGC demonstrates lost opportunities across multiple fisheries sectors, losses that could have been prevented with stronger fisheries management (Cisneros-Mata, 2020; see also Mangin et al., 2018).

In the 1920s a commercial fishery was established after an agreement between the United States and Mexico to develop a market for the whole fish (Cisneros-Mata et al., 1995). Totoaba soon became a highly prized commercial and sport fish, responding to a growing U.S. market where the fillets commanded high prices (Cisneros-Mata et al., 1995; True, 1996). As the fishery grew, early fishing methods evolved and efficient, large-mesh nylon gillnets became the preferred gear (Flanagan and Hendrickson, 1976). Annual yields increased rapidly and trade in totoaba with the U.S. promoted the development of roads and fishing infrastructure in the UGC communities (Flanagan and Hendrickson, 1976).

Fishing effort peaked in the 1940s. By the 1970s, totoaba landings had plummeted due to intensive overfishing, large numbers of juvenile totoaba bycaught in commercial shrimp trawls, and fishermen moving into the then more lucrative shrimp fishery (Cisneros-Mata et al., 1995; Cisneros-Mata, 2020). Mexico banned commercial and sport fishing for totoaba in 1975. The species was listed on CITES (Convention on International Trade in Endangered Species of Wild Fauna and Flora) Appendix 1 (1977), placed on the The U.S. Endangered Species List (1979) and the Mexican List of Endangered Species (1994), and has been listed as "Critically Endangered" by the IUCN since 1996 (but see Cisneros-Mata, 2020). Gillnets targeting totoaba were prohibited (1992) and trade in totoaba or any part of a totoaba is illegal under Mexican law, U.S. law, and CITES. Yet throughout this period, poaching of totoaba continued (Cisneros-Mata, 2020).

While there were some indirect indications of recovery of the totoaba by the early 2010s (Valenzuela-Quiñonez et al., 2015), a rapid and likely unsustainable resurgence of illegal fishing was also underway (Cisneros-Mata, 2020). The poaching has been driven by increasing demand in China where rising incomes and an expanding middle class fuel a market for totoaba swim bladders (known as "maw"), which are prized in traditional medicine and as gifts and investments (C4ADS, 2017; Crosta et al., 2018). Compounding the problem, criminal networks began trafficking in totoaba swim bladders and developed the black market, taking advantage of routes used for other illegal products, including narcotics (C4ADS, 2017; Crosta et al., 2018; Ladkani, 2019; Aceves-Bueno et al., 2020; Belhabib et al., 2020; Felbab-Brown, 2020).

The price of one kilogram of dried swim bladder in southern China has varied over time, ranging upwards of 20,000 to 80,000 USD or more (Environmental Investigation Agency [EIA], 2016a,b; Crosta et al., 2018). Most prized are the swim bladders of adult females, with large (over $1 \mathrm{~kg}$ ), high-quality swim bladders garnering the highest prices. At the peak of prices in 2012, such a swim bladder could fetch over 155,000 USD (Environmental Investigation Agency [EIA], 2016b). UGC fishers are reported to receive between 3,500 and up to 8,500 USD per kilogram (Environmental Investigation Agency [EIA], 2016b; C4ADS, 2017; Crosta et al., 2018), a fraction of the retail value but an enormous income for a local fisher relative to other income sources (for comparison, ex-vessel price for blue shrimp are $\sim 12$ USD per kilogram; Erisman et al., 2015), and a temptation otherwise honest fishers may not be able to resist (Aceves-Bueno et al., 2020). One night of fishing with a catch of a few totoabas can earn a fisher in the UGC more than what would be earned in one year of legal fishing (Crosta et al., 2018). Catching small totoabas will pay for the costs of fishing, but catching one or more large female totoabas is like winning the lottery; one fisher reported earning 116,000 USD in a single day of fishing (pers. comm. with local fishers ${ }^{4}$ ).

Given the expected revenues from totoaba poaching relative to revenues from legal fishing, prohibitions on totoaba fishing and the use of gillnets meet with considerable resistance from many fishers. Totoaba swim bladders have been dubbed 'aquatic cocaine' for their high value, and the illicit trade is enabled and fueled by corruption, poor enforcement, and lack of compliance with regulations (C4ADS, 2017; Crosta et al., 2018; Environmental Investigation Agency [EIA], 2019; FelbabBrown, 2020; Cisneros-Mata, 2020). Organized crime is gaining increasing control of the region's fishing activities, including for shark, shrimp, and corvina (C4ADS, 2017; Belhabib et al., 2020; pers. comm. with local fishers (see text footnote 4)). Organized criminal groups are also supplying gear and financing some of the costs of poaching, with some fishers becoming increasingly indebted to the cartels, making it even more difficult to break the cycle of illegal fishing or incentivize compliance with regulations (Crosta et al., 2018; Ladkani, 2019; Alberts, 2021). Social unrest and violence are becoming more frequent as fishers feel they have few alternatives, criminal networks compete for control, and illegal fishers clash with efforts to protect vaquita from gillnets (C4ADS, 2017; Crosta et al., 2018; International Union for the Conservation of Nature [IUCN], 2020a).

\section{Vaquita Bycatch and Status}

As with many small cetaceans around the world, gillnets present the greatest threat to vaquita survival (Rojas-Bracho and Taylor, 1999; Rojas-Bracho and Reeves, 2013; Brownell et al., 2019). Gillnets set for totoaba pose the greatest risk due to the intensity of fishing, overlap with core vaquita habitat, and fishing practices with large mesh size nets. Other potential threats that have been suggested, but no evidence exists to support them as significant risk factors, including inbreeding depression, pollutants, and ecological changes as a result of reduced flow from the Colorado River (Rojas-Bracho and Taylor, 1999; Brusca et al., 2017; Flessa et al., 2019; Gulland et al., 2020; Morin et al., 2020). Vaquita are listed under CITES Appendix 1 (1979), on the U.S. Endangered Species Act (1985) and the Mexican List of Species at Risk of Extinction (1994), and have been listed as "Critically Endangered" by the IUCN since 1996.

In 1997, the first abundance survey of vaquita estimated 567 individuals [95\% confidence interval (CI) 177 - 1,073]

\footnotetext{
${ }^{4}$ Local fishermen in San Felipe, personal communication to Lorenzo Rojas Bracho,
} communicated to the authors 
(Jaramillo-Legorreta et al., 1999). Just over a decade later, a visual and acoustic survey documented 245 animals (95\% CI 68-884) indicating an average annual decline of $7.6 \%$ attributed to mortality in gillnets set for shrimp and finfish (Gerrodette and Rojas-Bracho, 2011). Since the resurgence of gillnet poaching for totoaba, continued visual and acoustic monitoring of the population has documented a steep decline at about $50 \%$ per year (Thomas et al., 2017; Jaramillo-Legorreta et al., 2019). The number of vaquitas was estimated to be 59 in 2015 (Baysian Credible Interval (CRI) 22-145; Taylor et al.,

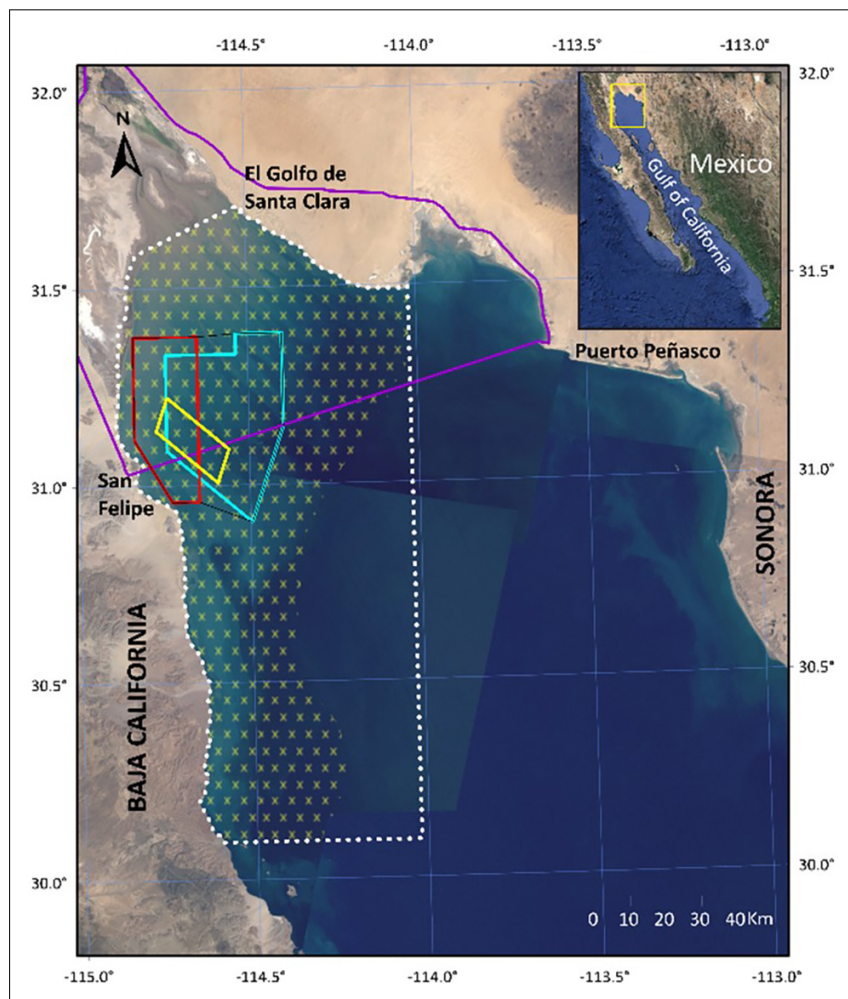

FIGURE 1 | Historical distribution of vaquitas (yellow hatched area) in the upper Gulf of California. The Upper Gulf of California and Delta of the Colorado River Biosphere Reserve (outlined in purple), designated by UNESCO in 1995, because of the unique habitat and presence of endangered species. The Vaquita Refuge (agreed to in 2005 and enacted in 2008 as a no fishing zone) is outlined in aqua blue. The gillnet exclusion zone (where fishing with gillnets is banned but other types of fishing are allowed) was given straight boundaries (dotted white) described by single latitude and longitude to facilitate enforcement and enacted in 2015 (Comité Internacional para la Recuperación de la Vaquita [CIRVA], 2014). Due to the drastic decline in vaquita numbers due to the resurgence of the illegal totoaba fishery, an enhanced enforcement zone (red) was recommended by Comité Internacional para la Recuperación de la Vaquita [CIRVA] (2017) in the area where the remaining vaquitas are thought to spend most of their time and that has high levels of illegal totoaba fishing effort. The Zero Tolerance Area (ZTA) is where CIRVA recommends nets must be removed within hours of being set (outlined in yellow). Despite these designations for vaquita protection, gillnets continue to be used and the population continues to decline toward extinction. Landsat satellite composite imagery provided by U.S. Geological Survey, National Aeronautics and Space Administration (NASA) and Esri, Inc. Projection UTM. Datum WGS84. Figure and caption adapted from Comité Internacional para la Recuperación de la Vaquita [CIRVA] (2019) and Jaramillo-Legorreta et al. (2019).
2016) and less than 19 in 2018 (CRI 6-19; Jaramillo-Legorreta et al., 2019). As noted above, a recent photo-identification effort focused in the area where vaquitas were most recently detected acoustically, estimated 10 individuals, including 3 calves (Rojas-Bracho et al., 2020). Researchers last sighted vaquitas in November 2020 (International Union for the Conservation of Nature [IUCN], 2020a). Since then, acoustic monitoring has been suspended for the season due to the intensity of illegal fishing.

Vaquita have the smallest range of any cetacean (Figure 1). The remaining individuals appear to inhabit a tiny area $\left(288 \mathrm{~km}^{2}\right.$ or roughly $12 \times 24 \mathrm{~km})$ designated as the Zero Tolerance Area (ZTA) (Comité Internacional para la Recuperación de la Vaquita [CIRVA], 2019). The ZTA lies within the legally defined Vaquita Refuge and within sight of San Felipe (Figure 1). There are a number of reasons to believe that if vaquitas were immediately protected from gillnets throughout their range, but particularly in the ZTA, the population could recover (International Whaling Commission [IWC], 2021). These few remaining vaquita appear in robust health, have low levels of pollutants, can calve every year (instead of every 2 years as formerly believed), and have persisted with low levels of genetic diversity but no signs of inbreeding depression (Taylor et al., 2019; Gulland et al., 2020; Morin et al., 2020; Rojas-Bracho et al., 2020). Yet, even if complete protection of these remaining vaquitas were guaranteed, recovery would take decades (Taylor et al., 2016, 2019). Saving vaquita therefore requires pursuing both immediate actions to prevent extinction and sustained, long-term efforts to permanently transition fisheries in vaquita habitat away from gillnets.

\section{NATIONAL POLICIES IN MEXICO FROM 2007 TO 2018}

Bobadilla et al. (2011) describe multiple periods of conservation action in the UGC. Initial efforts (1950-1970) focused on protecting commercial fish stocks; in a second period (19701990) efforts shifted toward social issues and promoting growth in small-scale fishing; and in a third period (1990-2007) the focus was on sustainable development. A fourth period, beginning in 2007, centered on single-species conservation driven by the steep decline of the vaquita population. Most of this paper addresses this fourth period, which featured a variety of policy instruments designed to reduce or eliminate gillnets in vaquita habitat and to compensate fishers for lost fishing income through economic instruments such as buyouts and other monetary compensation programs. The paper finishes with a brief update on 2019-present (early 2021), which has been characterized by a lack of cohesive national policies in the region and the enactment of international trade sanctions.

From 2007 to 2018, the Mexican government invested heavily (around 145M USD) to implement programs and actions to prevent the extinction of the vaquita while providing support for the local fishing communities (Figure 2, Table 1, and Appendix 2). In this period, three programs were implemented to reduce or eliminate gillnets in vaquita habitat while providing for 
the livelihoods of fishers and related industries: (1) Vaquita Conservation Program for Sustainable Development in 2007, (2) Action Program for the Conservation of Species from 2008 to 2015 (PACE-Vaquita), and (3) Plan for the Comprehensive Care of the Upper Gulf of California (Comprehensive Care Plan).

The Vaquita Conservation Program for Sustainable Development (2007) was part of PROCODES, a nationwide subsidy program of the National Commission of Natural Protected Areas (CONANP). The focus was to provide specific alternative livelihoods in exchange for fishing licenses (Comisión Nacional de Áreas Naturales Protegidas [CONANP], 2009). In 2007, the Government of Mexico announced the Program for the Conservation of Species at Risk (PROCER), and developed a more specific instrument for vaquita: the PACE-Vaquita (20082015). PACE-Vaquita was a voluntary, multi-faceted program with four main components:

(1) Buy-out with alternative livelihoods: granted fishers the opportunity to start a new business in exchange for permanently surrendering their fishing license(s) and was an extension of the PROCODES program. Between 2007 and 2014, 370 licenses were purchased.

(2) Rent-out: payment for ecosystem services program (PES) provided financial compensation for not fishing in the Vaquita Refuge (Figure 1). Around 876 fishing license owners participated in this program for three years, which basically turned the refuge into a No Take Zone (NTZ).

(3) Switch-out: provided opportunities for fishers to permanently exchange gillnets for other non-entangling fishing gears. A total of 370 fishers participated in this program.

(4) Alternative technology development: paid fishers for participating in tests to develop alternative methods of fishing without gillnets. In return, participants agreed not to use gillnets during the year of testing. Thirty-eight fishers participated in 2009 and up to 126 in 2010; after this time, participation was almost non-existent.

While the PACE program was showing some positive results with fishers, the vaquita population decline accelerated (Jaramillo-Legorreta et al., 2016). The worsening situation led the Government of Mexico to suspend the PACE program and implement a new strategy to save the species. The Comprehensive Care Plan was announced in 2015 and differed from the PACE in that the program was mandatory. It had four main components:

(1) An increase in the size of the NTZ from 126,000 to 1.3 million hectares (the Gillnet Exclusion Zone; Figure 1).

(2) The suspension of all small-scale fisheries from the Gillnet Exclusion Zone for two years. The new regulations prohibited only gillnets and longlines (sometimes also used to catch totoaba), but in practice the prohibition also included fishing with gears which were originally designed as alternatives to gillnets.

(3) Monetary compensation provided to fishers and related industries for the loss of income from the fishing ban; 109M USD from 2015 to 2018 .
(4) Enhanced enforcement effort and coordination with the support of the Mexican Navy and Federal Police.

Despite the unprecedented financial and political investment, the Comprehensive Care Plan also failed to end gillnet fishing in vaquita habitat and the vaquita population continued to decline. Fishers grew increasingly frustrated at the ban on earning a living from fishing with gillnets, the lack of effective enforcement against poaching, the inconsistent and insufficient support to develop alternative methods of fishing, and corruption and disparities in the government compensation system. The Center for Biological Diversity (CBD]) analyzed the distribution of government compensations among the fishing communities and found large disparities (13 individuals received $20 \%$ of the compensation; Olivera and Uhlemann, 2016), ${ }^{5}$ making a few individuals extremely wealthy while leaving some other families without adequate income support and compromising food security.

Table 1 underscores another important point, notably that payments to compensate fishers for not fishing in the NTZ (122M USD) significantly surpassed the investment in developing alternative fishing methods and alternative livelihoods (23.1M) (Table 1 and Appendix 2). Compensation was an emergency measure to support communities and buy time for vaquita, but the opportunity was missed to link future compensation payments to fishers' participation in efforts that would benefit vaquita conservation or rebuild the region's fisheries, economy, and community well-being, such as gear development and retraining programs (Comité Internacional para la Recuperación de la Vaquita [CIRVA], 2017).

In April 2017, the Government of Mexico declared extraction of endangered species a criminal felony comparable to organized crime (involving at least 3 fishers) (Diario Oficial de la Federación [DOF], 2017a) which was previously a minor offense. For the first time, those caught and convicted of totoaba poaching would be subject to a substantial fine. They would also be subject to a criminal trial and, if convicted, serve prison time (Diario Oficial de la Federación [DOF], 2017a). There has been inspections and seizures (Procuraduría Federal de Protección al Ambiente [PROFEPA], 2018), but few arrests, prosecutions, or penalties for illegal fishing, poaching, or trafficking in Mexico and respect for authority and rule of law is decreasing in the UGC (Expansión Política, 2019; FelbabBrown, 2020). For example, of 174 formal cases filed by PROFEPA for capture, trafficking, and distribution of totoaba products (Procuraduría Federal de Protección al Ambiente [PROFEPA], 2019), only $10-13 \%$ of the arrests received a criminal sanction (Rivera, 2018; Martinez, 2019). There were no convictions between December 2018 and the end of 2019 (Procuraduría Federal de Protección al Ambiente [PROFEPA], 2019) and there has been only one set of arrests in 2020 (El Universal, 2020).

\footnotetext{
${ }^{5}$ Some of the factors impacting the distribution of compensation funds could include political power (fishing leaders) and economic power (fishing cooperatives linked with buyers or those that have a concentration of licenses).
} 


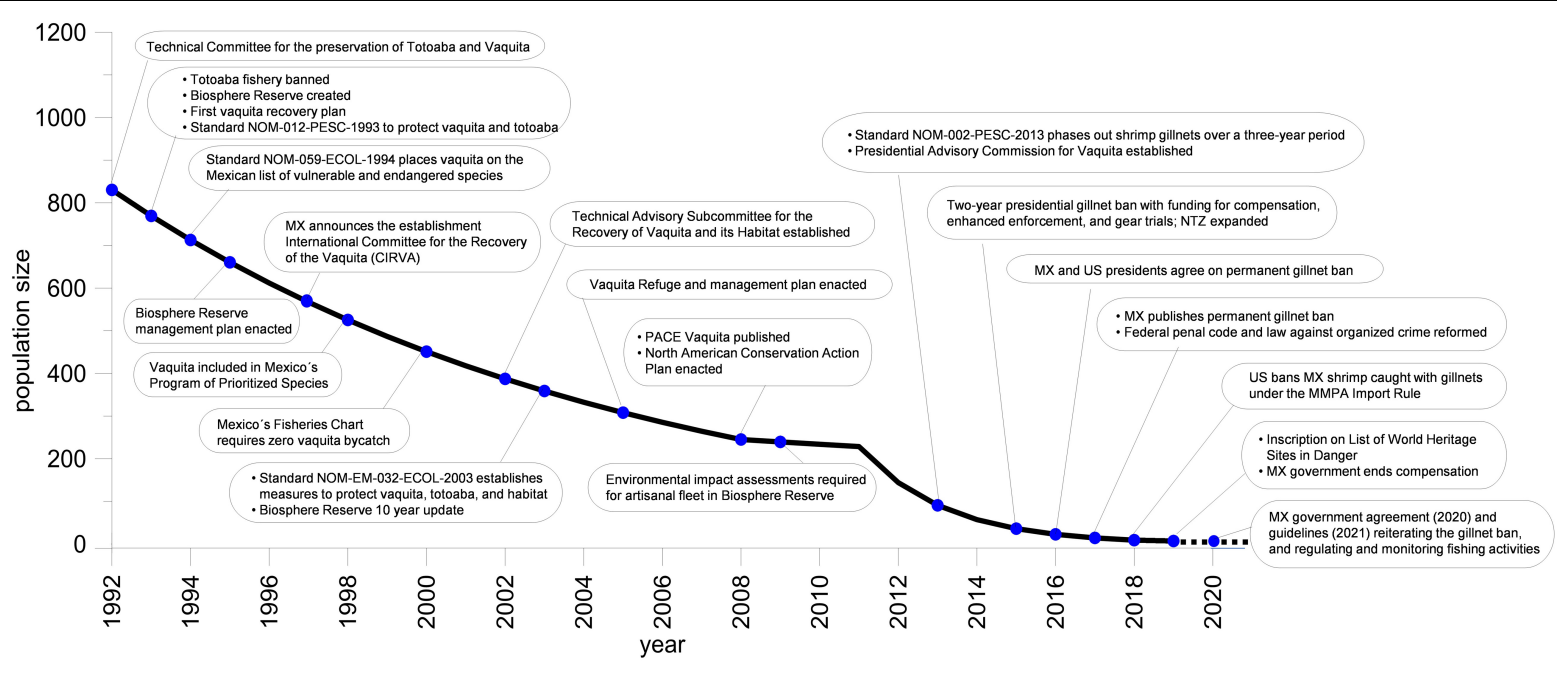

FIGURE 2 | The decline of vaquitas has been continual despite many laws and regulations being enacted to reduce vaquita bycatch, but not resulting in the elimination of gillnets in vaquita habitat. See text and reviews in Rojas-Bracho et al. (2006), Bobadilla et al. (2011), Rojas-Bracho and Reeves (2013), and Cisneros-Montemayor and Vincent (2016) for more information. Figure with schematic depiction of vaquita population trajectory adapted from Comité Internacional para la Recuperación de la Vaquita [CIRVA] (2014), Jaramillo-Legorreta et al. (2019), and Rojas-Bracho et al. (2020).

TABLE 1 | Summary of payments to fishers by the Government of Mexico to implement actions to protect vaquita from gillnets, 2007-2018.

\begin{tabular}{|c|c|c|c|}
\hline Policy Instrument & Expenditures & Intentions & Outcomes \\
\hline $\begin{array}{l}\text { Buy-outs with } \\
\text { alternative livelihoods }\end{array}$ & 12.7M USD & $\begin{array}{l}\text { Reduce fishing capacity and build } \\
\text { community options. }\end{array}$ & $\begin{array}{l}\text { Increased fishing effort with longer gillnets; limited } \\
\text { number of successful new businesses established; } \\
\text { participation decreases to zero as program is only } \\
\text { voluntary }\end{array}$ \\
\hline $\begin{array}{l}\text { Compensation for No } \\
\text { Take Zones }\end{array}$ & 122M USD & $\begin{array}{l}\text { Remove fishers from vaquita habitat } \\
\text { and maintain fisher income. }\end{array}$ & $\begin{array}{l}\text { Illegal fishing with gillnets in the No Take Zone increases } \\
\text { due to the increase in profitability and lack of sanctions } \\
\text { for totoaba poaching }\end{array}$ \\
\hline $\begin{array}{l}\text { Alternative gear and } \\
\text { preferential markets }\end{array}$ & 10.4M USD & $\begin{array}{l}\text { Provide alternative ways of fishing } \\
\text { without harming vaquita. }\end{array}$ & $\begin{array}{l}\text { No replacement for gillnets, market opportunity lost as } \\
\text { other products replace UGC shrimp, market access not } \\
\text { able to incentivize conservation actions; no eco-label } \\
\text { exists to address information externality; no data } \\
\text { available to assess net profitability of gillnet-free fisheries }\end{array}$ \\
\hline $\begin{array}{l}\text { Social participation in } \\
\text { decision making }\end{array}$ & - & $\begin{array}{l}\text { Promote community engagement in } \\
\text { decision making }\end{array}$ & $\begin{array}{l}\text { Suspended in 2015; no formal venue for regular } \\
\text { engagement among regional stakeholders exists }\end{array}$ \\
\hline
\end{tabular}

See Appendix 2 for annual breakdown of expenditures and additional explanation.

With vaquita continuing to die in gillnets, and under mounting pressure to save the species, the Government of Mexico published an agreement prohibiting the use of gillnets in June 2017 (previous versions had been temporary; Diario Oficial de la Federación [DOF], 2015, 2017b). In October, 2017, the Mexican Ministry of the Environment (SEMARNAT) led a team of international partners in an emergency field effort to rescue as many vaquitas as possible and temporarily place them in captivity with the goal of releasing them once gillnets were eliminated, but the effort was suspended when an animals died (Rojas-Bracho et al., 2019). Additional efforts to protect the remaining vaquitas include a program led by SEMARNAT, together with conservation organizations, the Mexican Navy, and local fishers to remove active and abandoned "ghost" gillnets in vaquita habitat. Between October 2016 and March 2020, approximately 1600 gillnets have been retrieved from vaquita habitat (Sea Shepherd Conservation Society, 2019; Comité Internacional para la
Recuperación de la Vaquita [CIRVA], 2019; International Union for the Conservation of Nature [IUCN], 2020a, unpublished data).

In December 2018, a new administration for the Government of Mexico was inaugurated and the compensation to fishers and related industries was discontinued (International Union for the Conservation of Nature [IUCN], 2020b). In September 2020, the administration published a new agreement (Diario Oficial de la Federación [DOF], 2020) and guidelines (Diario Oficial de la Federación [DOF], 2021) for the protection of the vaquita. The new agreement included: banning the use of gillnets and requiring that fishers surrender their nets within 60 days; establishing mandatory inspections on every fishing trip; and creating specific zoning rules for the ZTA, encompassing the area with the remaining vaquita sightings. To date, these policies have not been implemented and the testing and financing of new gear outlined in the agreement has not been enacted. This has led to the continuation of unauthorized fishing with gillnets for shimp 
and finfish, as well as illegal fishing for totoaba (International Union for the Conservation of Nature [IUCN], 2020b; Sea Shepherd Conservation Society, 2020). For the past several years, social unrest and protests, as well as law suits and appeals for compensation, have been increasing as fishers feel their way of life is under attack and they have no alternatives. Reports of violence by illegal fishers against net removal vessels, legal fishers, and Mexican authorities are also becoming more frequent (Comité Internacional para la Recuperación de la Vaquita [CIRVA], 2019; Expansión Política, 2019; Felbab-Brown, 2020; International Union for the Conservation of Nature [IUCN], 2020a).

The alarm over the declining status of vaquita and continuation of illegal fishing has triggered international attention. UNESCO initiated review and subsequently inscribed the Islands and Protected Areas of the Gulf of California on the List of World Heritage Sites in Danger (United Nations Educational, Scientific and Cultural Organization [UNESCO], 2019). In 2018, in response to litigation by conservation organizations, the United States banned the importation of fish and fish products caught with gillnets within the range of the vaquita under the new U.S. Marine Mammal Protect Act (MMPA) Import Provisions Rule (Federal Register [FR], 2018). The rule requires nations exporting fish and fish products to the United States to have marine mammal bycatch measures that are comparable in effectiveness to U.S. commercial fishing operations. The ban was followed by a finding of "comparability" that allowed imports of products caught in the same region with alternative vaquita-safe gears. However, the comparability finding has since been revoked because of Mexico's failure to implement a comparable regulatory program and to enforce existing regulations (Federal Register [FR], 2020).

Vaquita is also identified as an issue of concern in the new 2020 United States-Mexico-Canada Agreement (USMCA) on trade (United States Trade Representative [USTR], 2020). In addition, and in response to the lack of effective action to counter totoaba trafficking, CITES drafted a resolution to restrict Mexico's exports to international markets for more than 2000 listed species, representing an important source of foreign revenue into the country (Convention on International Trade in Endangered Species of Wild Fauna and Flora [CITES], 2019). While the deadline has been extended, the possibility of sanctions remains open, imposing a threat to important Mexican industries and livelihoods.

\section{REVIEW OF POLICY INSTRUMENTS}

The members of the NAAFE panel reviewed several of the key policy instruments implemented in the UGC to protect vaquita through an economic lens and evaluated the intended and unintended consequences of these policies. The following section provides a summary and further discussion of the main findings on four key instruments: buy-outs with alternative livelihoods, compensation for not fishing in the NTZ, alternative gear and markets, and social participation in decision making.

\section{Buy-Outs With Alternative Livelihoods}

The buy-out programs in the UGC were designed to provide financial incentives to fishers to turn in gillnets in exchange for funds to invest in alternative livelihoods. During PROCODES (2007), authorities offered limited investment options to fishers who opted to take part, while during the PACE (20082015) authorities provided a greater range of opportunities for investment by accepting proposals presented by the fishers. The buy-out programs were voluntary and required that participants permanently cancel their fishing licenses. Below, we discuss the effectiveness of the buy-out in building alternative livelihoods and as a measure to reduce fishing effort.

Ávila-Forcada et al. (2012) analyzed participation in the PACE program. They found that individual fishers' social, economic, and demographic characteristics influenced decisions on whether to participate in this voluntary program and determined the level of participation as the program progressed. For example, fishers with a single license preferred to avoid risk by retaining their license and continuing to fish, while fishers with multiple licenses were more likely to participate. In addition, fishers with skills in other economic activities were more likely to participate, as well as older fishers who took the opportunity to retire from fishing.

\section{Effectiveness of Building Alternative Livelihoods}

A preliminary survey conducted in 2011 revealed that after three to four years, $70 \%$ of new businesses financed with PACE had survived (Ávila-Forcada et al., 2020). The survey data were used to analyze the factors associated with the survival of these new ventures and found that the businesses more likely to survive were those operated by women, located in San Felipe, not involved in fishing or tourism, and co-financed with loans from other sources ${ }^{6}$. These results highlight the importance of focusing on women in fishing families and the key role of financial services in the transition to alternative livelihoods. They also highlight the importance of looking at the household as a relevant economic unit.

Despite this initial success, from 2010 to the end of PACE in 2015, participation of fishers in the buy-out program was close to zero. The decline in participation was associated with the reduction of the payment: buy-out payments decreased from a single payment of 59,701 USD in 2008 to 31,750 USD in 2010, and to 26,718 USD in $2014^{7}$ due to a lower budget for PACE

\footnotetext{
${ }^{6}$ Ávila-Forcada et al. (2020) classified the type of business in three categories: (1) tourist-oriented (cabins, restaurants, souvenir shops, and similar); (2) nontourist oriented (beauty salons, tortilla shops, stationery shops, and similar); and (3) fishery-related (freezer plants, aquaculture activities). The type of business was found to be a non-significant variable of the model.

${ }^{7}$ The payment was calculated as the lifetime value of a fishing permit, considering a discount rate of $10 \%$. The goal of the buy-out was to retire as many gillnets as possible within a defined budget. In economic terms, the government offered the terms of the buy-out as a "reverse auction," designed to minimize the amount expended in order to get as much product as possible; inputs are a target or a budget, with the price offered increasing each iteration. Reverse auctions are designed such that the buyer reveals the price to pay and the seller decides to sell or not, knowing that the price will go up but not knowing anything about the remaining budget. In the logic of a reverse auction, the amounts that the government of Mexico should present would increase year by year. However, the buy-out operated in the opposite direction with time than what would be recommended by auction theory (Barlow et al., 2010).
} 
(see Appendix 2). In addition to the reduction in the payment, the effectiveness of the program was limited due to the lack of malleability of human capital which is a barrier to exiting the fishing sector as described initially by Clark et al. (1979) and elaborated on by Clark and Munro (2017). Often, fishers are not ready or able to switch to other employment or to become small business entrepreneurs, and the UGC is no exception; those with malleable skills were those who were more apt to succeed in the program while most needed additional training to acquire competence in a different sector (Ávila-Forcada et al., 2012). There were attempts to train fishers in different trades, and an office established for a brief time to assist fishers (e.g., McGuire and Valdez-Gardea, 2008), but not enough support was devoted to this critical component in order for it to be successful. Ultimately, UGC fishers were not willing to give up the profits that could be made in the gillnet fisheries for which they were familiar and skilled. The profitability of these fisheries, along with little enforcement, and the money available from government compensation programs, provided strong incentives to remain fishing with gillnets.

Other obstacles to exiting the fishery included the lack of retirement plans for older fishers; low access to scholarships and training programs for young people prior to joining the fishing sector; and land tenure problems, especially in El Golfo de Santa Clara. Most of the fishers in this town have homes built on land they do not legally own (Bobadilla et al., 2011). If they leave the region, they do not have the certainty of keeping their home upon returning or the ability to profit from its sale. Lastly, the program coincided with the global economic recession, particularly that of the United States, which had adverse effects on the Mexican economy, including tourism (Villarreal, 2010).

The panel noted that for economic alternatives to be successful, it is critical to ensure well-functioning financial, property, and regulatory institutions that enable small business development. There are costs to switching professions, such as training, interest on loans, and opportunity costs for lost time before a new business becomes profitable, which may dissuade fishers from participating. The panel also noted that alternative livelihood efforts in the region only rarely considered the skills and needs of women or opportunities to strengthen the next generation by investing in education, food security, or health care, thereby limiting the ability of communities to evolve. There was agreement on the importance of establishing a diversified economy to avoid the dependency on one single sector and the need to allow local people to decide on the selection of alternatives.

\section{Effectiveness of Buy-Outs for Reducing Bycatch}

A buy-out program can perversely result in an increase in fishing effort. Fishers who take part in a buy-out could reinvest their funds to expand their fishing capacity on other vessels, such as by increasing the power of the engine or the size of the fishing gear (Clark et al., 2005; Curtis and Squires, 2007). This concept, known as capital stuffing, is defined as the tendency to invest in non-restricted inputs (such as hull, engine, gear) when one input (vessel number or size) is limited, often in response to regulations to limit entry or reduce fishing effort (Pope, 2009).
Prior to the buy-out program, Cudney-Bueno and TurkBoyer (1998) reported that a typical shrimp operation used two gillnets of $\sim 400$ meters each; after the buy-out, Pérez-Valencia et al. (2015) documented the use of two gillnets of 800 meters each. Cisneros-Montemayor (2017) used a static bio-economic model to analyze the economic rationale for increasing the size of gillnets. The starting point of the model is open access in which each panga (skiff) used 800 meters of gillnets. When introducing a buy-out into the model, the model shows an initial reduction of the number of pangas but an increase in the size of gillnet to 1,600 meters to return to the original equilibrium. This research, other studies of buy-out programs (Curtis and Squires, 2007), and anecdotal information from the UGC all suggest an increase in fishing capacity per unit of legal effort was a consequence of the buy-out (It is important to note the legal length of a gillnet in the UGC was 200 meters). Fishing capacity also reportedly increased due to an increase in the number of illegal new and "cloned" pangas ${ }^{8}$; an increase in engine capacity (new, bigger, dual motors); and an increase in the size of gillnets, or some combination of these Comité Internacional para la Recuperación de la Vaquita [CIRVA], 2014).

Considering the limited and then declining participation in PACE and PROCODES, the limitations on alternative livelihoods posed by non-malleable human capital, and the evidence that gillnet effort in vaquita habitat did not decline, the panel raised significant concerns about the buy-out programs for the UGC and the unintended consequence of an increase in gillnet length. The panel emphasized the importance of establishing a sound fisheries management system encompassing permits, capacity, effort, access rights, and gears, as a first condition for supporting bycatch policies, which then must be enforced.

\section{Compensation for Not Fishing in the No Take Zone}

The Vaquita Refuge, an area of 126,000 hectares, was created in 2005 and established as a NTZ in 2008. From 2008 to 2014, UGC fishers received compensation for not fishing in the NTZ, also known as a PES policy to protect biodiversity. Annual payments varied from 3,000 to 4,500 USD per panga (regardless of the number of licenses). As a point of comparison, net annual income per panga with a shrimp license in 2010 was estimated at 2200-2700 USD and for finfish 857-1935 USD in San Felipe and El Golfo de Santa Clara, respectively (Barlow et al., 2010). The PES program excluded any mechanisms to incentivize license holders to share the payment with their crew members. Information from a vessel tracking program during the period shows that fishing intensity inside the NTZ was lower than in the rest of the UGC (Erisman et al., 2015), reflecting some compliance and a reduction of fishing activity inside the NTZ, which encompassed half of the vaquita population in a relatively

\footnotetext{
${ }^{8}$ The term "cloning" here refers to the use of a single license to operate two or more pangas. Cloned pangas have the same type of engine and the same boat name and license number printed on the side of the vessel. They carry duplicate licenses on board and share any other components that would make it difficult to differentiate the original panga from the "cloned" one/s. Usually, cloned pangas are deployed at a distance from one another in order to avoid detection by the authorities.
} 
small area ${ }^{9}$. However, fishing effort was not reduced in the other half of the range of vaquitas, resulting in a higher density of nets outside the NTZ (Comité Internacional para la Recuperación de la Vaquita [CIRVA], 2014). In 2015, when vaquita numbers dropped to less than 100 individuals, the Mexican government enacted emergency measures to expand the NTZ - 10 times larger than the original area. The increase encompassed the full range of vaquita and the known areas of illegal gillnet fishing for totoaba.

Payments for not fishing in the NTZ also increased in 2015: pangas with three licenses received up to 2,000 USD for each month of the fishing season. Despite adoption of the emergency gillnet ban in 2015, and significant financial compensation coupled with a new scheme to provide a subsidy to workers in related industries, reports of illegal fishing activities for totoaba increased dramatically. The rate of decline of vaquita abundance was the highest recorded to this time, $49 \%$ a year (2015-2016; Thomas et al., 2017). CIRVA had recommended that instead of lump-sum payments, compensation should be given only if fishers invested in vaquita friendly gear or participated in gillnet-free fisheries (Comité Internacional para la Recuperación de la Vaquita [CIRVA], 2017). However, compensation was made on a regular basis with no requirements to participate in training or experimental gillnet-free fishing in exchange for the payments.

The panel noted the critical importance of considering the consequences of suspending legal fisheries for shrimp and finfish. While suspending legal fisheries reduced the risk to vaquita from gillnets used to target shrimp and finfish, the benefit was likely offset by increased incentive to target totoaba. The panel again highlighted the importance of a sound fishery management system, that is enforced, as a starting point in the establishment of a NTZ, which also needs to be developed in collaboration with the fishery sector. In other marine protected areas in the Gulf of California, fishing spillover, new opportunities for tourism, sportfishing, and commercial fishing, and continuous negotiations have compensated for the closure (Bobadilla Jiménez et al., 2017; Cisneros-Montemayor et al., 2020).

\section{Alternative Gear and Markets}

Beginning in 2004, experiments were conducted by the Government of Mexico, conservation organizations, academics, gear experts, and the fishing sector to develop and test promising gears that would allow fishers to make a living without risking vaquita entanglement (Herrera et al., 2017). A small number of fishers in the region have been key participants in these experiments, interested and willing to develop, test, and use alternative gears (PescaABC, 2017).

These early efforts identified a number of promising gear types with commercially viable catch ranges (catch rates were dependent on fisher skill; Herrera et al., 2017). However, the Mexican authorities failed to continue to make progress in

\footnotetext{
${ }^{9}$ Rojas-Bracho and Reeves (2013) explain the technical difficulties that fishers experienced in identifying the NTZ that made compliance difficult to follow.
}

transitioning UGC fisheries away from gillnets (United Nations Educational, Scientific and Cultural Organization [UNESCO], 2018). Efforts have continued to fall short, including in the development of new gears, providing the necessary permits, and securing safe places for fishermen to conduct trials on the water. Consequently, most UGC fishers remain reluctant to use alternative gear, claiming it produces less catch and preferring the gillnets that have been profitable to use for decades. For example, in 2013 an important regulation outlined a three-year phase out of shrimp gillnets at the UGC as part of a modification to the national standard for shrimp fishing NOM-002 (Diario Oficial de la Federación [DOF], 2013). The application of this standard was delayed because of the expansion of the NTZ in 2015, lack of enforcement, and the reluctance of the fishing community to accept the technological change. Those fishers willing to use new gears at the time were frequently not able to get the required experimental fishing permits from the fisheries authorities. They also lacked financial support and have been physically blocked from access to fishing areas by gillnet fishers. Researchers have not been able to complete critical cost-earnings analyses with sufficient data to estimate profitability, improve fishing methods, and develop markets.

As PACE ended in 2015, the efforts for testing and implementing alternative gear have been inconsistent and continue to fall far short of the effort and investment needed (United Nations Educational, Scientific and Cultural Organization [UNESCO], 2018; Comité Internacional para la Recuperación de la Vaquita [CIRVA], 2019). Some of the efforts since 2015 include the testing of suripera nets for shrimp and encircling techniques for corvina conducted by INAPESCA; tests with fish traps conducted by fishers in San Felipe from Pesca Alternativa de Baja California (PescaABC); trials of suripera nets and a traceability system for shrimp organized by Museo de la Ballena with local fishers, which were successful in harvesting commercially viable catches; and some trials with small trawls conducted by individual fishers who obtained a commercial permit for catching shrimp. All these efforts have been done without a systematic plan by the fisheries authorities, while most of the fleet is allowed to fish illegally with gillnets, often observed in the NTZ.

Gear experts agree that over time, the alternative gear is likely to become more efficient as fishers become familiar with their use and gear configurations are tailored for local conditions (Herrera et al., 2017). To complement these efforts, southern California seafood buyers and chefs have demonstrated interest in purchasing shrimp harvested with methods that do not endanger vaquita (Aquarium of the Pacific, 2016; Ocean Awards, 2016; Sustainable Fisheries Partnership, 2019). There has also been interest in linking committed producers to responsible consumers, applying a "vaquita friendly" ecolabel as an instrument to support fishers using vaquita-safe gears. Ecolabels and preferential markets have the potential to empower and reward fishers, such as in the form of a price premium or market access, for responsible fishing practices (Poindexter et al., 2017). Such an approach is particularly well-suited 
for the high-quality, large-sized, blue shrimp from the UGC (Mesnick et al., 2019).

The panel noted the importance of understanding the large amount of human and social capital invested in gillnet fisheries for the last half century, making change inherently difficult. They also noted the importance of legal markets that support fishers' ability to make a good living, as important insurance against the temptations of illegal markets (Felbab-Brown, 2017). The panel agreed on several points with respect to alternative gear and market opportunities. These included the critical need for fisheries authorities to facilitate the permitting, testing, and use of alternative gears and to take advantage of the expert technical advice provided by fishers themselves, as well as numerous gear technicians from government and academic research institutions. Verifiable and transparent seafood traceability systems are also indispensable requirements for conservation and market access, and fishers can be linked directly with buyers to address issues of asymmetric information. Finally, fishery management with stringent and enforced capacity and catch limits is key in ensuring that incentivizing policies will have the intended results.

Vaquita conservation in Mexico has been influenced, to some extent, by policies in other export market countries and multilateral fora. The ban under the U.S. MMPA import regulations, and the focus on vaquita and totoaba in the new USMCA trade agreement, has garnered attention and some action from the Government of Mexico, but has not stopped the use of gillnets in vaquita habitat. Fishers who continue to target shrimp with illegal gillnets may their product domestically, or it may be laundered and sold in the U.S. market (Felbab-Brown, 2020; Mendez, 2021; pers. comm. with Vaquita Enforcement Study Group ${ }^{10}$ ). Legal fishers using alternative gears are not able to access to the lucrative U.S. market, and opportunities to support these fishers through potential price premiums and niche market access in the U.S. are not possible at this time, but can be pursued in domestic markets. The ongoing poaching and trafficking of totoaba swim bladders also risks far-reaching sanctions under CITES for producers all across the country, but Mexico has not demonstrated that the vaquita and totoaba are effectively protected (Convention on International Trade in Endangered Species of Wild Fauna and Flora [CITES], 2019).

\section{Social Participation in Decision Making}

One of the most valuable, but often overlooked, aspects of the policies enacted in the UGC was the creation of the Group of Monitoring and Evaluation (OES) as part of PACE. OES held a total of 22 sessions from 2008 to 2013, averaging one meeting every 10 weeks. CONANP chaired OES which included other federal agencies, local governments, municipalities, conservation organizations, academics, and the fishing sector. Participants evaluated the progress of the

\footnotetext{
${ }^{10}$ Personal communication from the Vaquita Enforcement Study Group to the authors
}

policies and discussed adaptive management measures including compensations, changes in regulation, fishing management, alternative gear, and alternative livelihoods. OES could be defined as a formal cooperation-building approach for the government and the fishing sector, different from the numerous but ad hoc listening sessions held by the government agencies with the fishing sector, after OES ended. This participatory regulatory process played an important role in building buyin to comply with regulations. As Symes and Hoefnagel (2010) and Benham (2017) show, when the subjects of regulations participate in the design of the regulations, higher compliance is observed.

As a result of OES, the fishing sector agreed to present an Environmental Impact Assessment (EIA) in which the sector would report its expected fishing effort, recognize its impacts, and propose mitigation measures to reduce the negative impact on the ecosystems ${ }^{11}$. Using this instrument, attempts were made to control fishing effort, and legal fishers agreed to participate in monitoring activities (Pérez-Valencia et al., 2015).

In the arena provided by OES, the fishing sector was also able to present their own ideas for regulations and solutions. For example, a key discussion at OES was the length of gillnets. As noted above, regulations (for shrimp) established a gillnet length of 200 meters, yet fishers regularly used two gillnets of 800 meters in length. At OES meetings, the fishing sector proposed one gillnet of 600 meters in length. From the fishers perspective this meant a reduction of $62.5 \%$, while government officials perceived this as an increase of $300 \%$ from the legal level. The proposal did not pass, but this is an example of how the fishing sector was starting to participate in designing regulations that could balance vaquita protection with their own interests. While this was not the level of reduction called for by conservationists, it was an unprecedented offer presented by fishers themselves.

When switching from PACE to the Comprehensive Care Plan, OES disappeared, removing the only systematic venue for building relationships and developing the non-written norms and tools of engagement to help ensure buy-in with regulations. After OES, a Presidential Commission was created. The Presidential Commission was a closed group that included fisheries representatives but rarely included fishery sector stakeholders. Other agreements between Government of Mexico officials were made in closed sessions with fisheries representatives.

The panel and experts in social participation agree that having a constant framework for engagement allows space for cooperation to emerge (Leslie et al., 2015; Nenadovic and Epstein, 2016). A community fishery monitoring program for corvina in El Golfo de Santa Clara, which employs local women and is built with government support and a group of technical advisors, shows elements of such a framework (Environmental Defense Fund [EDF], 2021).

\footnotetext{
${ }^{11}$ Minutes of the 14th session of the OES, 10 June 2010.
} 


\section{DISCUSSION}

Although several policy instruments and unprecedented financial investments were made by the Government of Mexico in the UGC, they have been unsuccessful in eliminating the threat that gillnets pose to vaquita. We contend that a failure to prioritize and support alternative fishing methods and livelihoods for the coastal communities was a key missing component, compounded by the failure to address underlying issues of fisheries management and governance. Where these have failed, black markets, organized crime, and economic uncertainty have proliferated, driving ongoing use of gillnets and risk to vaquita. In this section, we examine how the current structure of incentives in the region makes illegal activities relatively more profitable for fishers, discuss the key factors undermining compliance with regulations, and make recommendations to improve outcomes.

\section{The Economics of Fishers' Compliance}

From an economic perspective, the willingness to participate in an illegal activity can be estimated based on three parameters: the expected payout from the illegal activity, the severity of the sanction (penalty) for participating in the illegal activity, and the probability of being sanctioned (caught, prosecuted, and convicted) (Becker, 1968; Freeman, 1999; among others). Sumaila et al. (2006) conducted cost-benefit analyses of global patterns in illegal, unreported, and unregulated (IUU) fishing that quantified these factors, finding that the expected benefits from IUU fishing far exceed the expected cost of being apprehended. Assuming a probability of being sanctioned equal to $20 \%$, the authors found that penalties would need to increase up to 24 times to equal the expected profitability of illegality (Sumaila et al., 2006).

\section{Expected Monetary Benefit From the Illegal Activity}

A fisher's choice is based on a comparison between the expected income from illegal fishing and expected income from a legal activity (fishing with alternative gears, fishing outside the exclusion areas, or taking a job that does not involve fishing). For illegal fishing, the expected net income is the net revenues minus the consequences of being caught. The consequences are the product of the probability of getting caught and sanctioned and the severity of the anticipated penalty. Given the relative values in this choice set, especially the high monetary value of totoaba swim bladders and very low likelihood of being caught and sanctioned, incentives remain very strong for UGC fishers to engage in illegal fishing.

\section{Penalty for Participating in the Illegal Activity}

As noted above, a federal resolution in 2017 declared illegal fishing a major felony comparable to organized crime (Diario Oficial de la Federación [DOF], 2017a), yet there have been few arrests or convictions. In the case of the UGC, both the penalty and the probability of being caught and prosecuted are low and both components should be evaluated. Setting the appropriate sanctions is complex and issues of fairness, political acceptance, and civil liberties need to be considered (Polinsky and Shavell, 2000; Felbab-Brown, 2017). Evidence from law enforcement demonstrates, however, that it is the probability of being sanctioned that is fundamental to creating deterrence effects (i.e., incentivizing people to comply), even far more so than the size of penalties (Kleiman, 2009).

\section{Probability of Being Sanctioned}

When expanding the NTZ, the Government of Mexico also significantly increased investment in surveillance, including personnel, high speed military-style boats, drones, and special cameras. However, there was not a clear strategy for using these technologies in enforcement (United Nations Educational, Scientific and Cultural Organization [UNESCO], 2018), and the efforts have not been well coordinated nor sustained. The jurisdiction among UGC enforcement agencies is complex and rules governing their activities limit effective action. Despite enforcement assets, and the possibility of criminal felony there is a lack of will by authorities to apply them; low and sporadic rates of effective arrest and prosecution result in low deterrence effects and therefore poor compliance in the region (Felbab-Brown, 2020).

Facing low probabilities of being caught and prosecuted, and high expected payoff for illegal activities, illegality becomes more attractive for many fishers in the UGC and can attract poachers from outside the area. Addressing the structure of incentives in the region requires a strategic approach that takes the full set of expected payouts and penalties into consideration so that regulations have the intended consequences.

\section{Factors Undermining Compliance}

Additional systemic factors and external pressures further undermine compliance with regulations and the effectiveness of policies to mitigate bycatch in the UGC, including the following.

\section{Weak Fisheries Management}

The panel noted a common point that complicated the implementation of the policies in the case of the UGC: the fishery lacks the most basic management measures, including any form of rights-based management. A history of weak fisheries management resulting in open-access, overcapitalized fisheries, keep UGC communities struggling for their livelihoods (Lluch-Cota et al., 2007; Erisman et al., 2011; Cisneros-Montemayor and Vincent, 2016; Pasini et al., 2017; Mangin et al., 2018; Aceves-Bueno et al., 2020). Moving toward rights-based fisheries management in the UGC is possible as seen in the case for corvina (Ortiz et al., 2016). Charles (2009) notes that defining fisheries rights aligns fishers' interests with management measures and therefore engenders greater compliance with fishery regulations.

\section{Complex Regulatory Environments Carry High Coordination Costs}

The UGC offers a particularly complex regulatory environment: multiple government agencies and multiple fishing organizations are involved in policy regulation and administration, requiring considerable coordination in designing and implementing environmental policies (Cisneros-Mata, 2020). Stronger 
collaboration amongst the fishing sector and regulators will lower transaction costs and improve information flow.

\section{Illegality and Corruption}

There is a longstanding history of corruption and tolerance to illegality that has surrounded fisheries in the UGC. Corruption is a key enabler of the illict totoaba trade (Environmental Investigation Agency [EIA], 2019). It undermines the ability of law enforcement to fight poaching and criminal networks and it reduces the deterrent effects of enforcement. Enforcement requires a strategic approach that embraces the entire compliance and enforcement chain (C4ADS, 2017; United Nations Educational, Scientific and Cultural Organization [UNESCO], 2018; Environmental Investigation Agency [EIA], 2019; AcevesBueno et al., 2020; Felbab-Brown, 2020). Enforcement and compliance with regulations in the UGC is also difficult because many fishers are willing participants in poaching and illegal fishing operations, view regulations as illegitimate or an imposition of conservation values that go against their economic interests (Felbab-Brown, 2018; Aceves-Bueno et al., 2020). In these cases, enforcement is both socially and politically unsustainable, as well as costly (Felbab-Brown, 2018). Building economic alternatives with the fishing community can be key to gaining acceptance and compliance, lowering the costs of enforcement, particularly when participants perceive regulations to serve their economic interests.

\section{Lack of Community Buy-In}

In addition to the probability and severity of sanctions, decisions to comply with regulations are also influenced by intrinsic motivations, as described by theories of psychology and sociology (Sutinen and Viswanathan, 1999; Squires et al., 2021). Consideration of these motivational inputs as well as social norms can contribute to building compliance. Examples of social norms that can be considered include social influence, moral values, sense of justice, and the perceived legitimacy of regulations (Hatcher et al., 2000). Participatory regulatory processes, in which participants are empowered to play a prominent role in decision making and where their views can be heard, may help achieve better compliance (Hanna, 1995).

However, it is important to note, that the role of individual private entities should be limited in the design of regulations to secure the public interest and avoid regulatory capture, which occurs when a regulatory agency is co-opted by the interests of a minority (Dal Bó, 2006). To address some of the regulatory capture problems, agencies can limit discretion and empower public interest groups, including other sectors and industries. When this can be accomplished, public participation can lead to efficient forms of cooperation that enhance the attainment of regulatory goals and strengthen democracy (Ayres and Braithwaite, 1991).

\section{Pressure From Outside of Mexico: Demand From Distant Markets}

The UGC finds itself at the crossroads of several global market forces. The U.S. demand for totoaba meat in the early years, and then shrimp, have been key drivers of vaquita bycatch. The market for totoaba swim bladders in Hong Kong and continental China results in derived demand and the current crisis. Chinese traffickers and Mexican cartels trafficking drugs to the U.S. market place additional outside pressures on the region (C4ADS, 2017; Crosta et al., 2018; Environmental Investigation Agency [EIA], 2019; Felbab-Brown, 2020). These external forces fuel poaching of totoaba and illegal fishing at the local level and empower criminal activity and corruption. The tools of traditional fisheries management are not sufficient to address these drivers (Aceves-Bueno et al., 2020). Tackling the complex supply chains linking fishers in the UGC and end consumers in distant markets requires a portfolio of policy instruments, enforcement tools, industry and government accountability, public information campaigns, and multidisciplinary expertise adapted for the special circumstances of reducing demand and trafficking in prohibited wildlife products (Felbab-Brown, 2017, 2018).

\section{Inequality, Impoverishment, and Crime}

Although the UGC has some of the most diverse and profitable fisheries resources in Mexico, the history of weak fisheries management, open access fisheries, and overcapitalization contributes to inequality and impoverishment, as is the case in fisheries around the country (Mangin et al., 2018). The literature on poverty and crime shows a positive correlation between absolute poverty and illegal activities (Patterson, 1991; Scorzafave and Soares, 2009; Short, 2018). In the UGC, the loss of income from the closure of gillnet fisheries and limited alternative sources of income were further compounded by the disparities created by the compensation plan. Some fishers with few alternatives turn to totoaba poaching and illegal fishing, risk becoming further trapped by debt to the cartels, and cannot exit (Ladkani, 2019; Alberts, 2021). As Felbab-Brown (2017), Aceves-Bueno et al. (2020), and others have pointed out, viewing poaching only as an activity of criminals ignores important underlying social injustices. Policies that compromise economic security may end up exacerbating the conditions that incentivized illegal activities in the first place (Cisneros-Montemayor and Vincent, 2016; Felbab-Brown, 2017; Aceves-Bueno et al., 2020).

\section{RECOMMENDATIONS}

Despite the very small area and the singular threat to survival, saving vaquita is complex, multi-faceted, and context dependent. It requires a holistic approach, using local knowledge, multidisciplinary expertise, and a broad range of tools and policy instruments. Solutions to eliminating vaquita bycatch require combining top-down regulations and effective enforcement with bottom-up, participatory, and incentive-based approaches to improve buy-in, and therefore bolster compliance with regulations. The holistic approach recognizes that illegal fishing in the UGC is not solely a problem of enforcement; it also reflects the social, economic, and political context of coastal communities. Not surprisingly, fisheries regulations that are seen as conflicting with the livelihoods of local fishers tend to provoke resistance (Gezelius and Hauck, 2011). Conservation needs to be 
designed and structured to benefit local communities through early and inclusive processes. Conservation actions should be geared to support legal fishermen in their ability to earn a living and to ensure they have a direct stake in a healthy marine ecosystem. These approaches require more time and a step-wise deliberative process, but will yield more long-lasting and effective results in addressing bycatch and wildlife trafficking. The panel recommends the following.

\section{Strengthen Fisheries Management With a Clear Definition of Access Rights}

Many of the issues in the region stem from a legacy of poor fisheries management with overcaptalized and mostly openaccess fisheries (Sumaila, 2012). Charles (2009) identifies the wide variety of access rights, noting two primary categories: (1) access rights specifying which vessels may participate in the fishery; and (2) harvest rights defined by species, gear, and time. Fishers within the region who are most impacted by restrictions should benefit from the resource through formal recognition of tenure rights (Cisneros-Montemayor and Vincent, 2016) whether in terms of rights to participate or rights to a share of the harvest.

\section{Build Solutions With Communities}

Increased participation in regulatory design is linked to increased compliance (Symes and Hoefnagel, 2010; Benham, 2017). Creating a fishery management system that empowers fishers as part of the decision-making process is key to building buy-in and therefore compliance. Such a participatory regulatory process can be built with broad community and institutional engagement so that trust, accountability, and legitimacy increase, and the political costs of enforcement are reduced (Gezelius and Hauck, 2011).

\section{Improve Enforcement}

Even with greater community buy-in, effective enforcement will remain key. Sustained enforcement needs to center on three points: intense enforcement in the vaquita's range to prevent the entry of gillnets into vaquita habitat, particularly the ZTA; robust enforcement in distant retail markets to reduce demand; and elimination of the operational layer of smuggling and organized criminal networks (Felbab-Brown, 2018, 2020). To have any hope of saving the last remaining vaquita, the speed and prevalence of prosecution that results in conviction need to radically increase in the UGC. This requires more effective deployment of detection and interdiction assets, full use of detection technologies, and greater diligence of authorities at the local, national, and international levels to enforce regulations. Cross-agency coordination, the prioritization of enforcement of the gillnet ban, and reduction of corruption among regulators and enforcers as well as the reduction of the political costs of enforcement, such as through the development of legal markets are also needed. Well-designed enforcement that is seen as legitimate by key stakeholders and is sustained, and sustainable, is essential for the effectiveness of conservation policies.

\section{Create an Optimal Structure of Sanctions}

To achieve an optimal level of deterrence, re-thinking the structure of sanctions in the UGC is needed, including consideration of fairness, pathways for offenders to avoid future violations, and the importance of swift, certain, and consistent levels of enforcement. In addition, and in a context of tolerated corruption such as the UGC, it is important to consider the possibility of including rewards to enforcement officers to avoid bribery (Polinsky and Shavell, 2001). Appropriate sanctions (including permit revocations, boat and catch seizures, fines, and prison terms) need to be commensurate with the socioeconomic condition of the offender and their level of involvement in illegal activities and not push low-level offenders farther into debt or illegality. Frequent violators should be fined at escalating rates, and fishing leaders as well as members of organized criminal groups arrested. Felbab-Brown (2017) describes that for law enforcement to have pronounced deterrence effects for homicide, for example, arrests and effective prosecutions need to reach about $40 \%$. Mexican laws and regulations are in place; the will to apply them is needed in order for sanctions to influence the decision to participate in illegal fishing or trafficking (FelbabBrown, 2017, 2020).

\section{Invest in Economic Opportunities}

To build compliance with conservation, and to counter the attraction of illegal activities, legal fisheries must be able to provide jobs, profits, and economic security (CisnerosMontemayor and Vincent, 2016; Felbab-Brown, 2017; Comité Internacional para la Recuperación de la Vaquita [CIRVA], 2019). Creation of alternative livelihood opportunities remains an urgent imperative in the UGC. Collaboration between fishers and fishing authorities, non-governmental organizations, gear experts, and industry must substantially increase to scale, develop, and socialize a comprehensive and transparent gear transition program, with explicit consideration of ecological capacity and impacts, as well as to design and implement a fisheries monitoring and traceability system. A broad range of livelihood alternatives needs to be considered (both on and off the water) that can yield comparable net income levels, and considering factors such as risk and preferences. It is equally important to consider the household as the relevant economic unit and evaluate the full spectrum of small businesses that provide services to the community, such as stationary shops, restaurants, beauty salons, etc. A broader array of economic activities can lead to more resilient coastal communities and increase compliance with policies that serve local economic interests (Cisneros-Montemayor and Vincent, 2016; Ávila-Forcada et al., 2020).

\section{Invest in Human Capital}

Crucial to sustainable development in the UGC is long-term investment in human capacity, gender equality, and other factors that enable individuals to create their own livelihood opportunities not exclusively dependent on fishing (CisnerosMontemayor and Vincent, 2016). Becoming a skilled fisher requires years of investment in human capital, which is lost 
when a fisher is asked to switch professions. Building capacities among fishers to learn other business skills, creating educational opportunities for young fishers or retirement for older ones, and solving land tenure problems for those willing to migrate, are just some of the alternatives for diversifying livelihood options in the community. Although controlling the overall fishing effort of the fishing fleet through some form of limits on access or output is an important part of improving fishery management, it can result in a smaller fleet and fishing labor force. Thus, investing in the malleability of human capital is essential. A broader perspective is needed to embrace the valuable contributions of women and to build short- and long-term opportunities for women and children, such as micro loans, education, and training.

\section{Use Market Tools, but With Caution}

Markets are powerful tools as the ultimate drivers of derived demand for fishing. Buyers, distributors, processors, and producers share responsibility for the legal provenance of their products and need to develop and implement a comprehensive chain of custody and traceability system that can be shown to hold all parts of the supply chain accountable for their sourcing. Bycatch conservation can be addressed by standards and certification and in consumer markets through ecolabels and information programs. However, the regulatory and traceability frameworks to prove compliance must be agreed upon beforehand, implemented, and verified. This also requires clear access rights and catch limits to avoid perversely incentivizing over-fishing which would act against conservation efforts. Domestic markets can be tested for small groups of fishers motivated to try methods that do not endanger vaquita, carry trackers, and linked to consumers seeking responsibly harvested seafood. Market tools can also be used to reduce demand for totoaba swim bladders as part of combatting illegal fishing for totoaba. Linked through organized crime throughout the market chain, the situation requires a comprehensive approach with partners who understand illicit trade and economies (Felbab-Brown, 2017; Aceves-Bueno et al., 2020). An interesting parallel can be found in the global effort to combat shark finning. Public statements by key Chinese government officials and celebrities helped reduce the demand for shark fin soup in the years 2007 to 2013 as did, crucially, the publicization of high content of dangerous mercury concentration in shark fins (Vallianos et al., 2018).

\section{REFERENCES}

Aburto-Oropeza, O., López-Sagástegui, C., Moreno-Báez, M., Mascareñas-Osorio, I., Jiménez-Esquivel, V., Johnson, A. F., et al. (2016). Endangered species, ecosystem integrity, and human livelihoods. Conserv. Lett. 11:e12358. doi: 10. $1111 /$ conl.12358

Aceves-Bueno, E., Read, A. J., and Cisneros-Mata, M. A. (2020). Illegal fisheries, environmental crime, and the conservation of marine resources. Conserv. Biol. doi: $10.1111 /$ cobi. 13674

\section{CONCLUDING REMARKS}

Every day the people of the UGC communities engage in economic activities to earn a living. What the economic perspective brings is a focus on developing a new structure of incentives in which legal activities benefit communities more than illegal activities. The urgency of the situation requires immediate actions to protect the remaining vaquita. The complexity of the situation requires an integrated, multifaceted approach to policies, combining technical expertise in gear and economic development, social participation in the regulatory process, socially relevant and structured incentives, and swift and certain enforcement of regulations. The situation for vaquita is dire, yet lessons from this case study may apply in other coastal, small-scale fisheries where conservation policies to reduce bycatch may be seen as conflicting with local economies, and more broadly in conservation issues around the globe.

\section{AUTHOR CONTRIBUTIONS}

OP, SM, ES-R, DS, and RL hosted the NAAFE workshop, "Saving the world's most endangered marine mammal: role of economic incentives for affected communities" in 2017. SÁ-F, AC-M, GM, RO-R, RR, JFS, and URS participated in the workshop and contributed to the ideas summarized here. OP prepared the initial meeting report which served as inspiration for the manuscript. ES-R, SM, RL, and SÁ-F conceptualized and wrote the manuscript. All authors made direct intellectual contributions to the work, refined key concepts, and approved the submitted version for publication.

\section{FUNDING}

The NAAFE workshop, "Saving the world's most endangered marine mammal: role of economic incentives for affected communities" was supported by World Wildlife Fund-Mexico and their generous donors.

\section{ACKNOWLEDGMENTS}

The manuscript was improved with thoughtful review and valuable comments from Lorenzo Rojas-Bracho, Barbara Taylor, Nina Young, Miguel Angel Cisneros-Mata, and two anonymous reviewers.

Alberts, E. C. (2021). In the Fight to Save the Vaquita, Conservationists Take on Cartels. Menlo Park, CA: Mongabay News.

Aquarium of the Pacific (2016). Storied Seafood: Vaquita Conservation. Available at: https://www.aquariumofpacific.org/seafoodfuture/vaquita_conservation

Ardjosoediro, I., and Bourns, N. (2009). Fisheries in Mexico's Upper Gulf of California: A Rapid Analysis of the Shrimp Value Chain, Alternatives, and Potential to Protect liveliHoods and Biodiversity. Washington, DC: The United States Agency for International Development (USAID). 
Ávila-Forcada, S., Martínez-Cruz, A. L., and Muñoz-Piña, C. (2012). Conservation of vaquita marina in the Northern Gulf of California. Mar. Policy 36, 613-622. doi: 10.1016/j.marpol.2011. 10.012

Ávila-Forcada, S., Martinez-Cruz, A. L., Rodriguez-Ramirez, R., and SanjurjoRivera, E. (2020). Transitioning to alternative livelihoods: the case of PACEVaquita. Ocean Coast. Manag. 183:104984. doi: 10.1016/j.ocecoaman.2019. 104984

Ayres, I., and Braithwaite, J. (1991). Tripartism: regulatory capture and empowerment. Law Soc. Inq. 16, 435-496. doi: 10.1111/j.1747-4469.1991. tb00291.x

Barlow, J., Rojas-Bracho, L., Munoz-Pina, C., and Mesnick, S. (2010). "Conservation of the vaquita (Phocoena sinus) in the Northern Gulf of California, Mexico," in Handbook of Marine Fisheries Conservation and Management, eds R. Q. Graton, R. Hilborn, D. Squires, M. Tait, and M. Williams (New York, NY: Oxford University Press), 205-214.

Becker, G. (1968). Crime and punishment: an economic approach. J. Political Econ. $76,169-217$

Belhabib, D., Le Billon, P., and Wrathall, D. J. (2020). Narco-fish: global fisheries and drug trafficking. Fish Fish. 21, 992-1007. doi: 10.1111/faf.12483

Benham, C. F. (2017). Aligning public participation with local environmental knowledge in complex marine social-ecological systems. Mar. Policy 82, 16-24. doi: 10.1016/j.marpol.2017.04.003

Bobadilla, M., Alvarez-Borrego, S., Ávila-Foucat, S., Lara-Valencia, F., and Espejel, I. (2011). Evolution of environmental policy instruments implemented for the protection of totoaba and the vaquita porpoise in the Upper Gulf of California. Environ. Sci. Policy 14, 998-1007. doi: 10.1016/j.envsci.2011. 06.003

Bobadilla Jiménez, M., Salguero, L., Montserrat, B., Lagunas Vázques, M., Álvarez Borrego, S., González Salazar, J. L., et al. (2017). Percepción de los Prestadores de Servicios Dentro de Áreas Naturales Protegidas Sobre la Eficacia de las Políticas Ambientales ahí Implementadas y su Impacto Sobre el Bienestar de la comunidad. Caso: Cabo Pulmo, BCS México. El Periplo Sustentable 33, 760-797. Periplo Sustentable [online]. UAEM. ISSN- 1870-9036.

Brownell, R. L. Jr. (1988). The vaquita: can it survive? Endanger. Species Techn. Bull. $8,7-8$.

Brownell, R. L. Jr., Reeves, R. R., Read, A. J., Smith, B. D., Thomas, P. O., Ralls, K., et al. (2019). Bycatch in gillnet fisheries threatens Critically Endangered small cetaceans and other aquatic megafauna. Endanger. Species Res. 40, 285-296. doi: 10.3354/esr00994

Brusca, R. C., Álvarez-Borrego, S., Hastings, P. A., and Findley, L. T. (2017). Colorado River flow and biological productivity in the Northern Gulf of California. Mexico. Earth Sci. Rev. 164, 1-30. doi: 10.1016/j.earscirev.2016.10. 012

C4ADS (2017). Hooked: How Demand for a Protected Fish Lined the Pockets of Mexican Cartels \& Sunk the Future of an Endangered Porpoise Species. Avliable at: https://c4ads.org/reports

Charles, A. (2009). "Use rights and the responsible fisheries: liming access and harvesting through rights-based management," in A Fishery Manageršs Guidebook, eds K. L. Cochrane and S. M. Garcia (Rome: The Food and Agriculture Organization of the United Nations and Wiley-Blackwell), 253-282.

Chute, G. R. (1928). The totuava fishery of the California Gulf. Calif. Fish Game 14, 275-281.

Chute, G. R. (1930). Seen Kow, a regal soup-stock. Calif. Fish Game 16, 23-35.

Cisneros-Mata, M. A., Montemayor-López, G., and Román-Rodríguez, M. J. (1995). Life history and conservation of Totoaba macdonaldi. Conserv. Biol. 9, 806-814. doi: 10.1046/j.1523-1739.1995.09040806.x

Cisneros-Mata, M. A. (2010). "The importance of fisheries in the Gulf of California and ecosystem-based sustainable co-management for conservation," in The Gulf of California: Biodiversity and Conservation, ed. R. C. Brusca (Tucson: University of Arizona Press), 119-135.

Cisneros-Mata, M. A. (2020). Evaluación de la Población de Totoaba Macdonaldi. Mexico City: Instituto Nacional de Pesca y Acuacultura.

Cisneros-Montemayor, A. M. (2017). Bioeconomic Analyses can Anticipate Pitfalls of Marine Conservation Policy. Abstract presented at the North American Association of Fisheries Economists Forum 2017. SP007. Avaliable at: https://ir. library.oregonstate.edu/concern/file_sets/8w32r968z
Cisneros-Montemayor, A. M., Cisneros-Mata, M. A., Harper, S., and Pauly, D. (2013). Extent and implications of IUU catch in Mexico's marine fisheries. Mar. Policy 39, 283-288. doi: 10.1016/j.marpol.2012.12.003

Cisneros-Montemayor, A. M., Townsel, A., Gonzales, C. M., Hass, A. R., NavarroHolm, E. E., Salorio-Zuñiga, T., et al. (2020). Nature-based marine tourism in the Gulf of California and Baja California Peninsula: economic benefits and key species. Nat. Resour. Forum 44, 111-128. doi: 10.1111/1477-8947. 12193

Cisneros-Montemayor, A. M., and Vincent, A. (2016). Science, society, and flagship species: social and political history as keys to conservation outcomes in the Gulf of California. Ecol. Soc. 21:9. doi: 10.5751/ES-08255-210209

Clark, C. W., Clarke, F. H., and Munro, G. R. (1979). The optimal exploitation of renewable resource stocks: problems of irreversible investment. Econ. J. Econ. Soc. 47, 25-47. doi: 10.2307/1912344

Clark, C. W., and Munro, G. R. (2017). Capital theory and the economics of fisheries: implications for policy. Mar. Resour. Econ. 32, 123-142. doi: 10.1086/ 690679

Clark, C. W., Munro, G. R., and Sumaila, U. R. (2005). Subsidies, buybacks, and sustainable fisheries. J. Environ. Econ. Manag. 50, 47-58. doi: 10.1016/j.jeem. 2004.11.002

Comisión Nacional de Áreas Naturales Protegidas [CONANP] (2009). Programa de Acción para la Conservación de la Especie: Vaquita (Phocoena sinus). Ciudad de México: Comisión Nacional de Áreas Naturales Protegidas. Reporte de avance físico-financiero y de metas. Informe final 2009.

Comisión Nacional de Áreas Naturales Protegidas [CONANP] (2010). Programa de Acción para la Conservación de la Especie: Vaquita. Ciudad de México: Comisión Nacional de Áreas Naturales Protegidas. Reporte de avance físicofinanciero y de metas. Informe final 2010.

Comisión Nacional de Áreas Naturales Protegidas [CONANP] (2011). Programa de Acción para la Conservación de la Especie: Vaquita 2011. Ciudad de México: Comisión Nacional de Áreas Naturales Protegidas. Cuarto trimestre del avance físico y financiero. Anexo número 7. Diciembre de 2011.

Comisión Nacional de Áreas Naturales Protegidas [CONANP] (2012). Programa de Acción para la Conservación de la Especie: Vaquita 2012. Ciudad de México: Comisión Nacional de Áreas Naturales Protegidas. Cuarto trimestre del avance físico y financiero. Anexo número 7. Diciembre de 2012.

Comisión Nacional de Áreas Naturales Protegidas [CONANP] (2013). Programa de Acción para la Conservación de la Especie. Ciudad de México: Comisión Nacional de Áreas Naturales Protegidas. Anexo 7. Reporte de avance físicofinanciero y de metas 2013.

Comisión Nacional de Áreas Naturales Protegidas [CONANP](2014). Programa de Acción para la Conservación de la Especie. Ciudad de México: Comisión Nacional de Áreas Naturales Protegidas. Anexo 7. Reporte de avance físicofinanciero y de metas 2014.

Comisión Nacional de Áreas Naturales Protegidas [CONANP] (2019). Libro Blanco del Programa de Recuperación y Repoblación de Especies en Riesgo (PROCER), Componente de Compensación Social para Contribuir a la Conservación de la Vaquita Marina. Ciudad de México: Comisión Nacional de Áreas Naturales Protegidas.

Comité Internacional para la Recuperación de la Vaquita [CIRVA] (2014). Report of the Fifth Meeting of the International Committee for the Recovery of Vaquita, CIRVA 5. Avaliable at: https://iucn-csg.org/downloads/

Comité Internacional para la Recuperación de la Vaquita [CIRVA] (2017). Report of the Tenth Meeting of the International Committee for the Recovery of Vaquita, CIRVA 10. Avaliable at: https://iucn-csg.org/downloads/

Comité Internacional para la Recuperación de la Vaquita [CIRVA] (2019). Report of the eleventh meeting of the International Committee for the Recovery of Vaquita. CIRVA 11. Avaliable at: https://iucn-csg.org/downloads/

Comité Internacional para la Recuperación de la Vaquita [CIRVA] (1997). Report of the Fifth Meeting of the International Committee for the Recovery of Vaquita, CIRVA 1. Burnaby, BC: CIRVA.

Convention on International Trade in Endangered Species of Wild Fauna and Flora [CITES] (2019). Totoaba (Totoaba macdonaldi). (2019). "Convention on International Trade in Endangered Species of Wild Fauna and Flora," in Eighteenth Meeting of the Conference of the Parties, Colombo, 23.

Crosta, A., Sutherland, K., Talerico, C., Layolle, I., and Fantacci, B. (2018). Operation Fake Gold: The Totoaba Supply Chain - From Mexico's Totoaba Cartels to China's Totoaba Maw Wholesalers - an Illegal Trade Killing the 
Vaquita. Los Angeles: Elephant Action League. Avaliable at: https://earth leagueinternational.org/wp-content/uploads/2018/07/EAL-Operation-FakeGold-Final.pdf

Cudney-Bueno, R., and Turk-Boyer, P. J. (1998). Pescando Entre Mareas del Alto Golfo de California: Una Guía Sobre la Pesca Artesanal, su Gente, y sus Propuestas de Manejo. Puerto Peñasco, Sonora. México: Centre Intercultural de Estudios de Desiertos y Océanos (CEDO) AC.

Curtis, R. E., and Squires, D. (2007). Fisheries Buybacks. Ames, IA: Blackwell.

D'Agrosa, C., Lennert-Cody, C. E., and Vidal, O. (2000). Vaquita bycatch in Mexico's artisanal gillnet fisheries: driving a small population to extinction. Conserv. Biol. 14, 1110-1119. doi: 10.1046/j.1523-1739.2000. 98191.x

Dal Bó, E. (2006). Regulatory capture: a review. Oxford Rev. Econ. Policy 22, 203-225. doi: 10.1093/oxrep/grj013

Diario Oficial de la Federación [DOF] (2013). Norma Oficial Mexicana NOM-002SAG/PESC-2013, Para Ordenar el Aprovechamiento de las Especies de Camarón en Aguas de Jurisdicción Federal de los Estados Unidos Mexicanos. Mexico City: Secretaría de Gobernación.

Diario Oficial de la Federación [DOF] (2015). Acuerdo Por el que se Suspende Temporalmente la Pesca Comercial Mediante el Uso de Redes de Enmalle, Cimbras y/o Palangres Operadas Con Embarcaciones Menores, en el Norte del Golfo de California. Mexico City: Secretaría de Gobernación.

Diario Oficial de la Federación [DOF] (2017a). Decreto por el que se Reforma el Artículo 420 del Código Penal Federal y se Adiciona el Artículo 2o. de la Ley Federal Contra la Delincuencia Organizada. Mexico City: Secretaría de Gobernación.

Diario Oficial de la Federación [DOF] (2017b). ACUERDO Por el que se Prohíben Artes, Sistemas, Métodos, Técnicas y Horarios Para la Realización de Actividades de Pesca con Embarcaciones Menores en Aguas Marinas de Jurisdicción Federal de los Estados Unidos Mexicanos en el Norte del Golfo de California, y se Establecen Sitios de Desembarque, así Como el uso de Sistemas de Monitoreo Para Dichas Embarcaciones. Mexico City: Secretaría de Gobernación.

Diario Oficial de la Federación [DOF] (2020). Acuerdo por el que se Regulan Artes, Sistemas, Métodos, Técnicas y Horarios Para la Realización de Actividades de Pesca con Embarcaciones Menores y Mayores en Zonas Marinas Mexicanas en el Norte del Golfo de California y se Establecen Sitios de Desembarque, así Como el uso de Sistemas de Monitoreo Para Tales Embarcaciones. Mexico City: Secretaría de Gobernación.

Diario Oficial de la Federación [DOF] (2021). Lineamientos para el Grupo de Colaboración Sobre Aplicación del Acuerdo por el que se Regulan Artes, Sistemas, Métodos, Técnicas y Horarios Para la Realización de Actividades de Pesca con Embarcaciones Menores y Mayores en Zonas Marinas Mexicanas en el Norte del Golfo de California y se Establecen Sitios de Desembarque, así Como el uso de Sistemas de Monitoreo para tales Embarcaciones. Mexico City: Secretaría de Gobernación.

El Universal (2020). Detienen a presunto líder del Cártel del Mar, dedicado al tráfico de Totoaba en Baja California. Avaliable at: https://www.eluniversal. com.mx/nacion/detienen-presunto-lider-del-cartel-del-mar-dedicado-al-tra fico-de-totoaba-en-baja-california (accessed November 11, 2020).

Environmental Defense Fund [EDF] (2021). How a Community-Based Fishery Program is Bringing Sustainability to Mexico's Upper Gulf of California. Avaliable at: https://blogs.edf.org/edfish/2021/04/20/how-a-communitybased-fishery-program-is-bringing-sustainability-to-mexicos-upper-gulf-ofcalifornia/?utm_source=twitter\&utm_campaign=edf-oceans_none_upd_ocn\& utm_medium=social- media\&utm_id=1618946504 (accessed April 20, 2021).

Environmental Investigation Agency [EIA] (2016a). Collateral Damage: How Illegal Trade in Totoaba Swim Bladders is Driving the Vaquita to Extinction. Avaliable at: https://eia-international.org/report/collateral-damage/

Environmental Investigation Agency [EIA] (2016b). Dual Extinction: The illegal trade in the endangered totoaba and its impact on the critically endangered vaquita. Briefing to the 66th Standing Committee of CITES. Avaliable at: https://eia-international.org/report/dual-extinction-the-illegal-trade-in-theendangered-totoaba-and-its-impact-on-the-critically-endangered-vaquita/

Environmental Investigation Agency [EIA] (2019). "CITES's last chance: stop the illegal totoaba trade to save the vaquita," in Briefing to the 18th Conference of the Parties to CITES and the 71st Standing Committee. Avaliable at: https: //reports.eia-international.org/savethevaquita/

Erisman, B., Mascarenas-Osorio, I., López-Sagástegui, C., Moreno-Báez, M., Jiménez-Esquivel, V., and Aburto-Oropeza, O. (2015). A comparison of fishing activities between two coastal communities within a biosphere reserve in the Upper Gulf of California. Fish. Res. 164, 254-265. doi: 10.1016/j.fishres.2014. 12.011

Erisman, B. E., Paredes, G. A., Plomozo-Lugo, T., Cota-Nieto, J. J., Hastings, P. A., and Aburto-Oropeza, O. (2011). Spatial structure of commercial marine fisheries in Northwest Mexico. ICES J. Mar. Sci. 68, 564-571. doi: 10.1093/ icesjms/fsq179

Expansión Política (2019). El Enfrentamiento Entre Pescadores y Marinos Que Causó Protestas en Baja California. Avaliable at: https://politica.expansion. $\mathrm{mx} / \mathrm{mexico} / 2019 / 03 / 28 /$ el-enfrentamiento- entre-pescadores- $y$ - marinos-quecauso-protestas-en-bc (accessed March 29, 2019).

Federal Register [FR] (2018). Fish and Fish Product Import Provisions of the Marine Mammal Protection Act List of Foreign Fisheries. Avaliable at: https://www. govinfo.gov/content/pkg/FR-2018-03-16/pdf/2018-05348.pdf

Federal Register [FR] (2020). Implementation of Fish and Fish Product Import Provisions of the Marine Mammal Protection Act; Revocation of Comparability Findings and Implementation of Import Restrictions; Certification of Certain Fish Products From Mexico. Avaliable at: https://www.govinfo.gov/content/pkg/FR2020-03-09/pdf/2020-04692.pdf

Felbab-Brown, V. (2017). The Extinction Market: Wildlife Trafficking and How to Counter It. Oxford: University Press.

Felbab-Brown, V. (2018). To counter wildlife Trafficking, Local Enforcement, not en-Route Interdiction, is Key. Menlo Park, CA: Mongabay News. Available at: https://news.mongabay.com/2018/01/to-counter-wildlife-traffickinglocal-enforcement-not-en-route-interdiction-is-key-commentary/ (accessed January 19, 2018).

Felbab-Brown, V. (2020). Saving the Vaquita Marina and the Urgency of This Fall. Avaliable at: https://www.brookings.edu/blog/order-from-chaos/2020/10/12/ saving-the-vaquita-marina-and-the-urgency-of-this-fall/ (accessed October $12,2020)$.

Flanagan, C. A., and Hendrickson, J. R. (1976). Observation on the commercial fishery and reproductive biology of the totoaba. Cynoscion macdonaldi, in the northern Gulf of California. Fish. Bull. 74, 531-544. Avaliable at: https://spo.nmfs.noaa.gov/content/observations-comm ercial-fishery-and-reproductive-biology-totoaba-cynoscion-macdonaldi

Flessa, K. W., Calderon-Aguilera, L., Cintra-Buenrostro, C. E., Dettman, D. L., Dietl, G. P., Goodwin, D. H., et al. (2019). Vaquita face extinction from bycatch. Comment on Manjarrez-Bringas, N. et al., lessons for sustainable development: marine mammal conservation policies and its social and economic effects. Sustainability 11:2161. doi: 10.3390/su11072161

Freeman, R. B. (1999). "The economics of crime," in Handbook of Labor Economics, Vol. 3, eds O. Ashenfelter and D. Card (Elsevier Science B.V.), 3530-3571.

Gezelius, S. S., and Hauck, M. (2011). Toward a theory of compliance in state-regulatedălivelihoods: A comparative study of compliance motivations in developed and developing world fisheries. Law \& Society Rev. 45, 435-470.

Gerrodette, T., and Rojas-Bracho, L. (2011). Estimating the success of protected areas for the vaquita, Phocoena sinus. Mar. Mamm. Sci. 27, e79-e100. doi: 10.1111/j.1748-7692.2010.00449.x

Gulland, F., Danil, K., Bolton, J., Ylitalo, G., Okrucky, R. S., Rebolledo, F., et al. (2020). Vaquitas (Phocoena sinus) continue to die from bycatch not pollutants. Vet. Record 187:e51. doi: 10.1136/vr.105949

Hanna, S. (1995). "Efficiencies of user participation in natural resource management," in Property Rights and the Environment: Social and Ecological Issues, eds S. Hanna and M. Munasinghe (Washington, DC.), 59-67.

Hatcher, A., Jaffry, S., Thébaud, O., and Bennett, E. (2000). Normative and social influences affecting compliance with fishery regulations. Land Econ. 76, 448461. doi: $10.2307 / 3147040$

Herrera, Y., Sanjurjo, E., and Glass, C. (2017). Report on alternative gear to gillnets in the Upper Gulf of California. Expert Committee on Fishing Technologies. Avaliable at: http://ecoft.info/

International Union for the Conservation of Nature [IUCN] (2020a). December 2019-February 2020 Vaquita Update. IUCN-SSC Cetacean Specialist Group. 
Avaliable at: https://iucn-csg.org/december-2019-february-2020-vaquitaupdate/

International Union for the Conservation of Nature [IUCN] (2020b). Vaquita IUCN SSC Cetacean Specialist Group/Vaquita. Avaliable at: https://iucn-csg.org/ vaquita/

International Union for the Conservation of Nature [IUCN] (2021). Vaquita Update October Through December 2020. IUCN-SSC Cetacean Specialist Group. Avaliable at: https://iucn-csg.org/vaquita-update-october-through-december2020/

International Whaling Commission [IWC] (2019). Report of the Scientific Committee SC68A. J. Cetacean Res. Manage. (Suppl.) 21, 1-308. Available at: https://archive.iwc.int/pages/view.php?ref=13044\&k=

International Whaling Commission [IWC] (2021). Report of the Scientific Committee SC68B. J. Cetacean Res. Manage. (Suppl.) 22, 1-122. Available at: https://archive.iwc.int/pages/view.php?ref=17766\&k=

Jaramillo-Legorreta, A., Cardenas-Hinojosa, G., Nieto-Garcia, E., Rojas-Bracho, L., Ver Hoef, J., Moore, J., et al. (2016). Passive acoustic monitoring of the decline of Mexico's critically endangered vaquita. Conserv. Biol. 31, 183-191. doi: 10.1111/cobi.12789

Jaramillo-Legorreta, A. M., Cardenas-Hinojosa, G., Nieto-Garcia, E., Rojas-Bracho, L., Thomas, L., Ver Hoef, J. M., et al. (2019). Decline towards extinction of Mexico's vaquita porpoise (Phocoena sinus). R. Soc. Open Sci. 6:190598. doi: 10.1098/rsos. 190598

Jaramillo-Legorreta, A. M., Rojas-Bracho, L., and Gerrodette, T. (1999). A new abundance estimate for vaquitas: first step for recovery. Mar. Mamm. Sci. 15, 957-973. doi: 10.1111/j.1748-7692.1999.tb00872.x

Kleiman, M. A. (2009). When Brute Force Fails: How to Have Less Crime and Less Punishment. Princeton, NJ: Princeton University Press.

Ladkani, R. (2019). Sea of Shadows. [Film]. Vienna: Terra Mater Factual Studios.

Leslie, H. M., Basurto, X., Nenadovic, M., Sievanen, L., Cavanaugh, K. C., Cota-Nieto, J. J., et al. (2015). Operationalizing the social-ecological systems framework to assess sustainability. Proc. Natl. Acad. Sci. U.S.A. 112, 5979-5984. doi: $10.1073 /$ pnas. 1414640112

Lluch-Cota, S. E., Aragón-Noriega, E. A., Arreguín-Sánchez, F., Aurioles-Gamboa, D., Bautista-Romero, J. J., and Sierra-Beltrán, A. P. (2007). The Gulf of California: review of ecosystem status and sustainability challenges. Prog. Oceanogr. 73, 1-26. doi: 10.1016/j.pocean.2007.01.013

Mangin, T., Cisneros-Mata, M. A., Bone, J., Costello, C., Gaines, S. D., McDonald, G., et al. (2018). The cost of management delay: the case for reforming Mexican fisheries sooner rather than later. Mar. Policy 88, 1-10. doi: 10.1016/j.marpol. 2017.10.042

Martinez, S. (2019). Sentencian 13.5\% de Detenidos por Tráfico de Totoaba, El Imparcial. Avaliable at: https://www.elimparcial.com/mexicali/mexicali/ Predomina-impunidad-en-trafico-de-totoaba-20190827-0040.html (accessed August 28, 2019).

McGuire, T. R., and Valdez-Gardea, G. C. (2008). Endangered species and precarious lives in the upper Gulf of California. Cult. Agric. 19, 101-107. doi: 10.1525/cag.1997.19.3.101

Mendez, E. (2021). Ningún Pescador del Hábitat de la Vaquita Marina Entregó sus Redes Prohibidas. Excelsior. Avaliable at: https://www.excelsior.com.mx/ nacional/ningun-pescador-del-habitat-de-la-vaquita-marina- entrego-susredes-prohibidas/1432192 (accessed February 11, 2021).

Mesnick, S. L., Poindexter, O., Sanjuro, E., Eguchi, T., Squires, D., and Lent, R. (2019). "Socio-economic incentives for vaquita conservation: unrealized opportunities and daunting challenges," in Abstract presented at the World Marine Mammal Conference, Barcelona. Available at: https://www.wmmconf erence.org/wp-content/uploads/2020/02/WMMC-Book-of-Abstracts-3.pdf

Morin, P. A., Archer, F. I., Avila, C. D., Balacco, J. R., Bukhman, Y. V., Chow, W., et al. (2020). Reference genome and demographic history of the most endangered marine mammal, the vaquita. Mol. Ecol. Resour. 2020, 1-13. doi: 10.1111/1755-0998.13284

Nenadovic, M., and Epstein, G. (2016). The relationship of social capital and fishers' participation in multi-level governance arrangements. Environ. Sci. Policy 61, 77-86. doi: 10.1016/j.envsci.2016.03.023

Norris, K. S., and Prescott, J. H. (1961). Observations on Pacific cetaceans of Californian and Mexican waters. Univ. Calif. Publ. Zool. 63, 291-402.

North, D. C. (1990). Institutions, Institutional Change and Economic Performance. Cambridge: Cambridge University Press.
Ocean Awards (2016). Winner Rob Ruiz Restaurateur. Winner for his Campaign to Conserve Vaquita Porpoise and Promotion of Using Shrimp Caught Without use of Gillnets. London: Boat International. Available at: https://www.boat international.com/luxury-yacht-events/ocean-awards/winners-of-the-oceanawards-29051

Olivera, A., and Uhlemann, S. (2016). Buscan Sanciones Comerciales Contra México en la Lucha para Salvar a Marsopa en Desaparición. Arizona: Center for Biological Diversity. Available at: https://www.biologicaldiversity.org/news/ press_releases/2016/totoaba-y-vaquita-06-28-2016.html

Ortiz, R., Mascareñas-Osorio, I., Román, R., and Castro, J. (2016). Biological and fisheries monitoring of the Gulf Corvina in the Upper Gulf of California. San Diego, CA: DataMares. doi: 10.13022/M38590

Pasini, Y. A., Rivas Soto, M., Anzures-Aguilar, M., Rojas-Ortega, L., and OliveraBonilla, A. (2017). Vaquita marina: En Que te Hemos Fallado. Ciudad de México: Greenpeace Mexico, A.C. Available at: https://www.greenpeace. org/static/planet4-mexico-stateless/2019/03/5e84a344-reporte-vaquitamarina.pdf

Patterson, E. B. (1991). Poverty, income inequality, and community crime rates. Criminology 29, 755-776. doi: 10.1111/j.1745-9125.1991.tb01087.x

Pérez-Valencia, S. A., Gorostieta-Monjaraz, M., Castañeda-Fernández, de Lara, V., Polanco-Mizquez, E. I., Rodriguez-Uceda, A., et al. (2015). MIA-R Para la Pesca Ribereña Responsable en la Reserva de la Biosfera Alto Golfo de California y Delta del Río Colorado: Alto Golfo de California. Puerto Peñasco: Centro Intercultural de Estudios de Desiertos y Océanos, A.C.

PescaABC (2017). Report of Participation in Planning Workshop of Gear Development in the Upper Gulf of California. Avaliable at: http://pescaabc.org/ en/lo-nuevo/

Poindexter, O., Mesnick, S., Lent, R., and Squires, D. (2017). The Value of Ecolabels Through Revealed Consumer Preferences for Seafood in San Diego County. Abstract presented at the North American Association of Fisheries Economists Forum, La Paz 2017. SS043. Avaliable at: https://ir.library.oregonstate.edu/ concern/file_sets/8w32r968z

Polinsky, A., and Shavell, S. (2000). The Fairness of sanctions: some implications for optimal enforcement policy. Am.Law Econ. Rev. 2, 223-237. doi: 10.1093/ aler/2.2.223

Polinsky, A., and Shavell, S. (2001). Corruption and optimal law enforcement. J. Public Econ. 81, 1-24. doi: 10.1016/S0047-2727(00)00127-4

Pope, J. (2009). "Input and output controls: the practice of fishing effort and catch management in responsible fisheries," in A Fishery Manager's Guidebook, eds K. L. Cochrane and S. M. Garcia (Rome: The Food and Agriculture Organization of the United Nations), 220-252.

Procuraduría Federal de Protección al Ambiente [PROFEPA] (2018). Informe de Actividades. Avaliable at: https://www.gob.mx/profepa/documentos/informede-actividades-profepa-2018.

Procuraduría Federal de Protección al Ambiente [PROFEPA] (2019). Esfuerzos Para la Protección de la Vaquita Marina y la Totoaba. Avaliable at: https://www.gob.mx/profepa/es/articulos/esfuerzos-para-la-proteccionde-la-vaquita-marina-y-la-totoaba?idiom=es (accessed November 2019).

Rivera, A. (2018). Totoaba. Condenados sólo 10\% por tráfico. Mexico City: El Universal. Available at: https://www.eluniversal.com.mx/nacion/sociedad/ condenados-solo-10-por-trafico-de-totoaba- un- pez-mas-caro-que-lacocaina

Rojas-Bracho, L., Brusca, R. C., Álvarez-Borrego, S., Brownell, R. L. Jr., CamachoIbar, V., Ceballos, G., et al. (2019). Unsubstantiated claims can lead to tragic conservation outcomes. BioScience 69, 12-14. doi: 10.1093/biosci/biy138

Rojas-Bracho, L., and Reeves, R. R. (2013). Vaquitas and gillnets: Mexico's ultimate cetacean conservation challenge. Endanger. Species Res. 21, 77-87. doi: 10.3354/esr00501

Rojas-Bracho, L., Reeves, R. R., and Jaramillo-Legorreta, A. (2006). Conservation of the vaquita Phocoena sinus. Mamm. Rev. 36, 179-216. doi: 10.1111/j.13652907.2006.00088.x

Rojas-Bracho, L., Taylor, B. L., Jaramillo-Legorreta, A., Olson, P., Ruiz, D., Hidalgo, E., et al. (2020). Survey Report for Vaquita Photographic Identification Research 2019. Avaliable at: https://iucn-csg.org/wp-content/uploads/2020/03/ 2020-Vaquita-Field-Report.pdf

Rojas-Bracho, L., and Taylor, B. L. (1999). Risk factors affecting the vaquita (Phocoena sinus). Mar. Mamm. Sci. 15, 974-989. doi: 10.1111/j.1748-7692.1999. tb00873.x 
Scorzafave, L. G., and Soares, M. K. (2009). Income inequality and pecuniary crimes. Econ. Lett. 104, 40-42. doi: 10.1016/j.econlet.2009. 03.021

Sea Shepherd Conservation Society (2019). Sea Shepherd Removes over 1000 Pieces of Illegal Fishing Gear From Vaquita Habitat. Avaliable at: https://seashepherd.org/news/sea-shepherd-removes-over-1000-pieces-ofillegal-fishing-gear-from-vaquita-habitat/

Sea Shepherd Conservation Society (2020). Unbridled Poaching as 80 Skiffs Raid Habitat of Critically Endangered Vaquita Porpoise. Avaliable at: https://seashepherd.org/news/sea-shepherd-reveals-unbridled-poachingas-80-skiffs-raid-habitat-of-critically-endangered-vaquita-porpoise/

Short, J. F. Jr. (2018). Poverty, Ethnicity, and Violent Crime. London: Routledge.

Squires, D., Ballance, L. T., Dagorn, L., Dutton, P. H., and Lent, R. (2021). Mitigating bycatch: novel insights to multidisciplinary approaches. Front. Mar. Sci. 8:613285. doi: 10.3389/fmars.2021.613285

Sumaila, U. R. (2012). Seas, oceans and fisheries: a challenge for good governance. The Round Table, Commonwealth J. Int. Aff. 101, 157-166. doi: 10.1080/ 00358533.2012.661532

Sumaila, U. R., Alder, J., and Keith, H. (2006). Global scope and economics of illegal fishing. Mar. Policy 30, 696-703. doi: 10.1016/j.marpol.2005. 11.001

Sustainable Fisheries Partnership (2019). Seafood Importers Backing Groups in Protecting Vaquita. Sustainable Fisheries Partnership Press Release. Avaliable at: https://www.sustainablefish.org/News/Seafood-importers-backing-groupsin-protecting-vaquita (accessed March 18, 2019).

Sutinen, J. G., and Viswanathan, K. K. (1999). A Socio-economic theory of regulatory compliance. Int. J. Soc. Econ. 26, 174-193. doi: 10.1108/ 03068299910229569

Symes, D., and Hoefnagel, E. (2010). Fisheries policy, research and the social sciences in Europe: challenges for the $21^{\text {st }}$ century. Mar. Policy 34, 268-275. doi: 10.1016/j.marpol.2009.07.006

Taylor, B. L., Rojas-Bracho, L., Moore, J., Jaramillo-Legorreta, A., Ver Hoef, J. M., Cardenas-Hinojosa, G., et al. (2016). Extinction is imminent for Mexico's endemic porpoise unless fishery bycatch is eliminated. Conserv. Lett. 10, 588595. doi: 10.1111/conl.12331

Taylor, B. L., Wells, R. S., Olson, P. A., Brownell, R. L. Jr., Gulland, F. M., and Read, A. J. (2019). Likely annual calving in the vaquita, Phocoena sinus: a new hope? Mar. Mamm. Sci. 35, 603-1612. doi: 10.1111/mms.12595

Thomas, L., Jaramillo-Legorreta, A., Cardenas-Hinojosa, G., Nieto-Garcia, E., Rojas-Bracho, L., Ver Hoef, J. M., et al. (2017). Last call: passive acoustic monitoring shows continued rapid decline of critically endangered vaquita. J. Acoust. Soc. Am. 142, e512-e517. doi: 10.1121/1.5011673

True, C. (1996). Is aquaculture the answer for the endangered totoaba? World Aquacul. 47, 38-43.

United Nations Educational, Scientific and Cultural Organization [UNESCO] (2018). Report on the Joint UNESCO World Heritage Centre/IUCN Reactive Monitoring Mission to Islands and Protected Areas of the Gulf of California
(Mexico). Available at: https://whc.unesco.org/en/list/1182/documents/ (accessed February 12-16, 2018).

United Nations Educational, Scientific and Cultural Organization [UNESCO] (2019). State of the Conservation Properties Inscribed on the World Heritage List, Forty-third Session of the World Heritage Committee (Baku, 2019). WHC/19/43.COM/7B.Add. Available at: https://whc.unesco.org/en/soc/3915

United States Trade Representative [USTR] (2020). Agreement between the United States of America, The United Mexican States, and Canada. Available at: https://ustr.gov/trade-agreements/free-trade-agreements/unitedstates-mexico-canada-agreement/agreement-between

Valenzuela-Quiñonez, F., Arreguín-Sánchez, F., Salas-Márquez, S., García-De León, F. J., Garza, J. C., Román-Rodríguez, M. J., et al. (2015). Critically endangered totoaba, Totoaba macdonaldi: signs of recovery and potential threats after a population collapse. Endanger. Species Res. 29, 1-11. doi: 10.3354/ esr00693

Vallianos, C., Sherry, J., Hofford, A., and Baker, J. (2018). Sharks in Crises: Evidence of Positive Behavioral Change in China as New Threats Emerge. San Francisco, CA: WildAid.

Villarreal, M. A. (2010). The Mexican Economy After the Global Financial Crisis. Washington, D.C: Library of Congress. CRS R41402, Congressional Research Service.

Author Disclaimer: The scientific results and conclusions, as well as any views or opinions expressed herein, are those of the authors and do not necessarily reflect the views of NOAA or the Department of Commerce (SM and DS) or the International Whaling Commission (RL).

Conflict of Interest: OP was employed by Ocean Associates, Inc.

The remaining authors declare that the research was conducted in the absence of any commercial or financial relationships that could be construed as a potential conflict of interest.

Publisher's Note: All claims expressed in this article are solely those of the authors and do not necessarily represent those of their affiliated organizations, or those of the publisher, the editors and the reviewers. Any product that may be evaluated in this article, or claim that may be made by its manufacturer, is not guaranteed or endorsed by the publisher.

Copyright (c) 2021 Sanjurjo-Rivera, Mesnick, Ávila-Forcada, Poindexter, Lent, Felbab-Brown, Cisneros-Montemayor, Squires, Sumaila, Munro, Ortiz-Rodriguez, Rodriguez and Sainz. This is an open-access article distributed under the terms of the Creative Commons Attribution License (CC BY). The use, distribution or reproduction in other forums is permitted, provided the original author(s) and the copyright owner(s) are credited and that the original publication in this journal is cited, in accordance with accepted academic practice. No use, distribution or reproduction is permitted which does not comply with these terms. 
Appendix 1 | Number of pangas and licenses in the Upper Gulf of California. Adapted from Pérez-Valencia et al. (2015).

\begin{tabular}{|c|c|c|c|c|c|c|}
\hline \multirow[t]{2}{*}{ Town } & \multirow[t]{2}{*}{ Number of pangas } & \multicolumn{5}{|c|}{ Number of fishing licenses } \\
\hline & & \multicolumn{3}{|c|}{ Gillnet fisheries } & \multicolumn{2}{|c|}{ Non-gillnet fisheries } \\
\hline San Felipe & 304 & 242 & 220 & 32 & 36 & 20 \\
\hline El Golfo de Santa Clara & 451 & 415 & 423 & 33 & 32 & 11 \\
\hline
\end{tabular}

Other species include octopus, clams, scallops, and other shellfish.

Appendix 2 | Payments to fishers by the Government of Mexico to implement actions to protect vaquita from gillnets (1,000's USD), $2007-2018$.

\begin{tabular}{|c|c|c|c|c|c|}
\hline Year & $\begin{array}{c}\text { Gear } \\
\text { Substitution }\end{array}$ & Buy-out & $\begin{array}{l}\text { Compensation } \\
\text { No Take Zone }\end{array}$ & $\begin{array}{l}\text { Technical Gear } \\
\text { Development }\end{array}$ & TOTAL \\
\hline 2007 & 380 & 2,784 & 0 & 0 & 3,163 \\
\hline 2009 & 1,731 & 536 & 1,480 & 509 & 4,257 \\
\hline 2010 & 1,179 & 23 & 1,841 & 1,941 & 4,984 \\
\hline 2011 & 0 & 0 & 2,385 & 0 & 2,385 \\
\hline 2014 & 761 & 344 & 796 & 928 & 2,829 \\
\hline 2015 & 0 & 0 & 30,210 & 0 & 30,210 \\
\hline 2016 & 0 & 0 & 27,639 & 0 & 27,639 \\
\hline 2017 & 0 & 0 & 28,243 & 0 & 28,243 \\
\hline 2018 & 0 & 0 & 23,066 & 0 & 23,066 \\
\hline
\end{tabular}

All figures are in 1000's USD based on the average Mexican peso to US dollar exchange rate for each year. Figures correspond exclusively to monetary transfers to fishers from the Government of Mexico (mainly administered by the Ministry of the Environment, SEMARNAT). Figures do not include financial costs of enforcement, which increased significantly during the years of the Comprehensive Care Plan (beginning in 2015). Summary of monetary investment by the Mexican government in the four main components of strategies to remove gillnets from vaquita habitat: gear substitution, buy-outs, compensation for not fishing in the No Take Zone, and investment in technological development of alternative fishing gear. Monetary payments and compensation to fishers effectively ended in 2018. Adapted from Comisión Nacional de Áreas Naturales Protegidas [CONANP], 2009; 2010; 2011; 2012; 2013; 2014; 2019. 